\title{
Pharmaceutical and Personal Care Products in Different Matrices: Occurrence, Pathways, and Treatment Processes
}

\author{
Nash Jett D. G. Reyes, Franz Kevin F. Geronimo, Kimberly Ann V. Yano, Heidi B. Guerra (D) and Lee-Hyung Kim * \\ Civil and Environmental Engineering Department, Kongju National University, Cheonan City 31080, Korea; \\ reyesnashjettdg@gmail.com (N.J.D.G.R.); fkgeronimo@kongju.ac.kr (F.K.F.G.); \\ kimannyano@gmail.com (K.A.V.Y.); heidiguerra@kongju.ac.kr (H.B.G.) \\ * Correspondence: leehyung@kongju.ac.kr
}

check for updates

Citation: Reyes, N.J.D.G.; Geronimo, F.K.F.; Yano, K.A.V.; Guerra, H.B.; Kim, L.-H. Pharmaceutical and Personal Care Products in Different Matrices: Occurrence, Pathways, and Treatment Processes. Water 2021, 13, 1159. https://doi.org/10.3390/ w13091159

Academic Editors: Urszula Kotowska and Joanna Karpińska

Received: 31 March 2021

Accepted: 20 April 2021

Published: 22 April 2021

Publisher's Note: MDPI stays neutral with regard to jurisdictional claims in published maps and institutional affiliations.

Copyright: (c) 2021 by the authors. Licensee MDPI, Basel, Switzerland. This article is an open access article distributed under the terms and conditions of the Creative Commons Attribution (CC BY) license (https:/ / creativecommons.org/licenses/by/ $4.0 /)$.
Abstract: The procedures for analyzing pharmaceuticals and personal care products (PPCPs) are typically tedious and expensive and thus, it is necessary to synthesize all available information from previously conducted research. An extensive collection of PPCP data from the published literature was compiled to determine the occurrence, pathways, and the effectiveness of current treatment technologies for the removal of PPCPs in water and wastewater. Approximately $90 \%$ of the compiled published papers originated from Asia, Europe, and the North American regions. The incomplete removal of PPCPs in different water and wastewater treatment processes was widely reported, thus resulting in the occurrence of PPCP compounds in various environmental compartments. Caffeine, carbamazepine, diclofenac, ibuprofen, triclosan, and triclocarban were among the most commonly reported compounds detected in water and solid matrices. Trace concentrations of PPCPs were also detected on plants and animal tissues, indicating the bioaccumulative properties of some PPCP compounds. A significant lack of studies regarding the presence of PPCPs in animal and plant samples was identified in the review. Furthermore, there were still knowledge gaps on the ecotoxicity, sub-lethal effects, and effective treatment processes for PPCPs. The knowledge gaps identified in this study can be used to devise a more effective research paradigm and guidelines for PPCP management.

Keywords: emerging pollutants; pharmaceuticals and personal care products; treatment technologies

\section{Introduction}

Emerging pollutants (EPs) consist of wide spectra of chemical compounds that can potentially lead to several environmental issues. These chemicals can occur naturally or can be manufactured synthetically for various industrial, medical, and other practical daily life applications. Despite the common notion that EPs are new substances that have been recently developed or produced, the majority of these chemicals have been already present in the environment for a long time [1]. The majority of EPs occur at trace concentrations, usually in the nanograms or micrograms per liter range. Conventional analytical methods and instruments were not capable of detecting compounds at very low concentrations and thus, the presence of EPs in various matrices were not studied until the recent developments in detection technologies [2,3]. Apart from instrumentation constraints, the innumerable sources and modes of EP transport into the environment can lead to large uncertainties in terms of the identification and quantification of compounds. As early as 2004, approximately seven million organic and inorganic substances were commercially available worldwide; however, among these substances, only three percent were inventoried or regulated and only 126 compounds were included in the US Environmental Protection Agency's (US EPA) list of priority pollutants [4,5]. There are more than 180 million compounds indexed by the American Chemical Society (CAS Registry ${ }^{\circledR}$ ) at present and the probability of synthesizing new compounds is still high due to the further advancements in the field of research and development [6]. 
Pharmaceuticals and personal care products (PPCPs) constitute one of the largest groups of EPs. PPCPs generally pertain to medications and therapeutic drugs that are used to treat or prevent diseases in animals or humans. These compounds are also present in cosmetics and personal hygiene products to promote the overall improvement of health and well-being [7]. Most PPCPs have the unique property of inducing physiological effects at low doses, making them potent compounds capable of altering the biological processes in different organisms. Certain PPCPs are not persistent and undergo various degradation processes, but the continuous consumption and introduction of these chemicals in the environment grant them a 'pseudo-persistent' characteristic [8]. One of the earliest pieces of evidence about the potential occurrence of PPCPs in the environment was reported by Garrison et al. in 1976, wherein the presence of clofibric acid in the Big Blue River wastewater effluent was documented [9]. The following year, Hignite and Azarnoff (1977) also published a study about the detection of clofibric acid and salicylic acid on sewage effluent [10]. The knowledge about PPCPs was very scarce until the 1990s, due to the constraints in analytical methods and instrumentation [11].

At present, the occurrence of PPCPs in various environmental compartments and their potential ecotoxicological effects have initiated extensive research and policy-making strategies to address the emerging environmental concerns. A number of studies regarding the occurrence, ecotoxicity, and treatment technologies for the removal of PPCPs in wastewater have been conducted in line with the progress in monitoring schemes and analytical techniques [12-20]. Despite the growing interest of the scientific community in PPCPs, several knowledge gaps remain due to the relatively small number of compounds being analyzed at different sample matrices. The procedures for PPCP analyses are typically tedious and expensive. The majority of the studies are focused on the quantification of pre-selected or targeted analytes rather than the identification of all the compounds present in the samples. In order to identify the priority compounds for the development of environmental management guidelines and identify the gaps that need to be further explored, it is necessary to synthesize the available information from previously conducted research. This review compiled an extensive collection of PPCP data from the published literature. The occurrence of various PPCP compounds in different matrices was highlighted to identify the potential sources and pathways of these compounds in the environment. The advancements in PPCP treatment technologies were also discussed to evaluate the potential strategies of limiting the presence of PPCPs in the environment. Ultimately, the key points established in this review can serve as a baseline for the development of new monitoring strategies and guidelines for future research undertakings.

\section{Methods}

A standard engine search of literature published in academic journals using the keyword "Pharmaceuticals and personal care products" was conducted in Google Scholar to compile PPCP data from different countries. Studies conducted from 2011 to 2020 were considered to ensure that the data collected were relevant and timely. The initial search results yielded a total of 519 published works (i.e., articles, reviews, theses, and books). Pertinent information such as the site location, type of sample matrix, and year of publication were also documented to analyze the trends of PPCP research over the past decade. PPCP concentration data in different matrices were obtained from a downsized list of 133 studies following the detailed selection criteria illustrated in Figure 1. The concentration of PPCPs in surface water, groundwater, soil and sediment, plants, and animals were compiled to determine the environmental concentrations of these compounds. The presence of PPCPs in wastewater (raw and treated), sludge, and drinking water were also examined to identify the potential pathways of PPCP deposition in the environment. Review papers and books were not considered in the synthesis to maintain the time frame (2011 to 2020) of data collection and to prevent the potential duplication of values. PPCP concentrations from laboratory-scale experiments using synthetic solutions or mixtures were also excluded to effectively reflect the PPCP concentrations in real samples. 


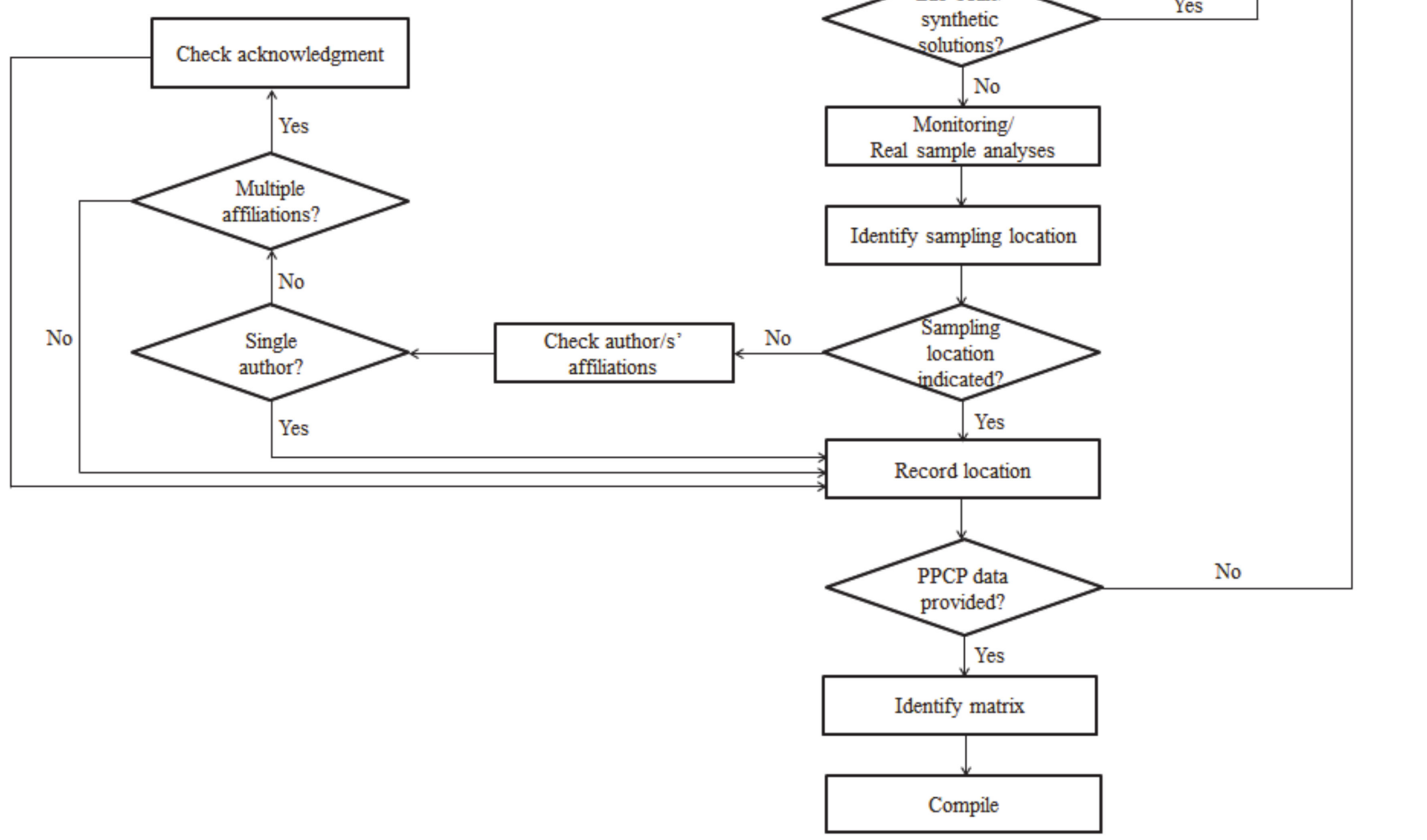

Figure 1. Paper selection criteria and collection framework for PPCP concentration data.

\section{Results and Discussion}

\subsection{Trends in PPCP Research}

The growing awareness regarding the occurrence of PPCPs in different environmental compartments and matrices prompted a gradual increase in the number of publications concerning PPCPs over the last decade. The total number of publications from the base year (2011) increased by $97 \%$ in the year 2020. On a continental scale, Asia, Europe, and the North American regions were found to be the leading contributors in PPCP research. More than $90 \%$ of the collated research articles concerning PPCPs published in the last decade originated from these regions. Apart from the increasing awareness and interest in PPCP research, higher publication outputs can also signify advancements in analytical methods and instrumentation techniques. Significant progress in PPCP research was noted in the period between 2000 and 2010. Analytical techniques using mass spectrometers such as Orbitrap, quadrupole $(\mathrm{Q})$ with linear ion-trap (QTRAP), and Q with time-of-flight (QToF) enabled the detection of compounds with extremely low concentrations (pg/L to $\mu \mathrm{g} / \mathrm{L}$ ranges). Since 2006, a huge leap in the number of publications and abstracts presented in different scientific platforms was observed alongside the development of advanced detection schemes for PPCPs [21,22].

The majority of the published literature were from China (127 research papers), the United States (121 research papers), and Spain (30 research articles). China is considered as the largest consumer and producer of PPCPs in the world due to its rapid economic development and population growth $[23,24]$. Some recent publications from Chinese 
institutions focused on the occurrence of PPCPs in major waterways, the development of reliable analytical methods for the detection of PPCPs, and ecological risk assessments for different PPCP compounds [25-28]. Due to the high probability of environmental contamination by PPCPs in China, extensive research efforts have been made in the region. The United States is one of the earliest countries that acknowledged the need to study the occurrence of PPCPs in wastewaters and natural environments. In the year 1999, the United States Geological Survey (USGS) initiated the first nationwide reconnaissance of 139 streams in 30 states to establish baseline data of the occurrence of PPCPs in natural waterways [29]. The procedure proposed by the United States Environmental Protection Agency for the analysis of PPCPs in water, solid, and aqueous samples also remains one of the most commonly used approaches in numerous research undertakings. In recent years, the productivity of PPCP research in the United States continues to expand, especially in terms of treatment processes and the toxicity of PPCPs in aquatic environments [30-32]. Several countries in the European region have also participated in the publication of PPCPrelated studies. Among the European countries, Spain contributed the largest number of papers in the compiled set of literature (31 research papers) over the past decade. The detailed number of publications concerning PPCPs in different countries is graphically illustrated in Figure 2.

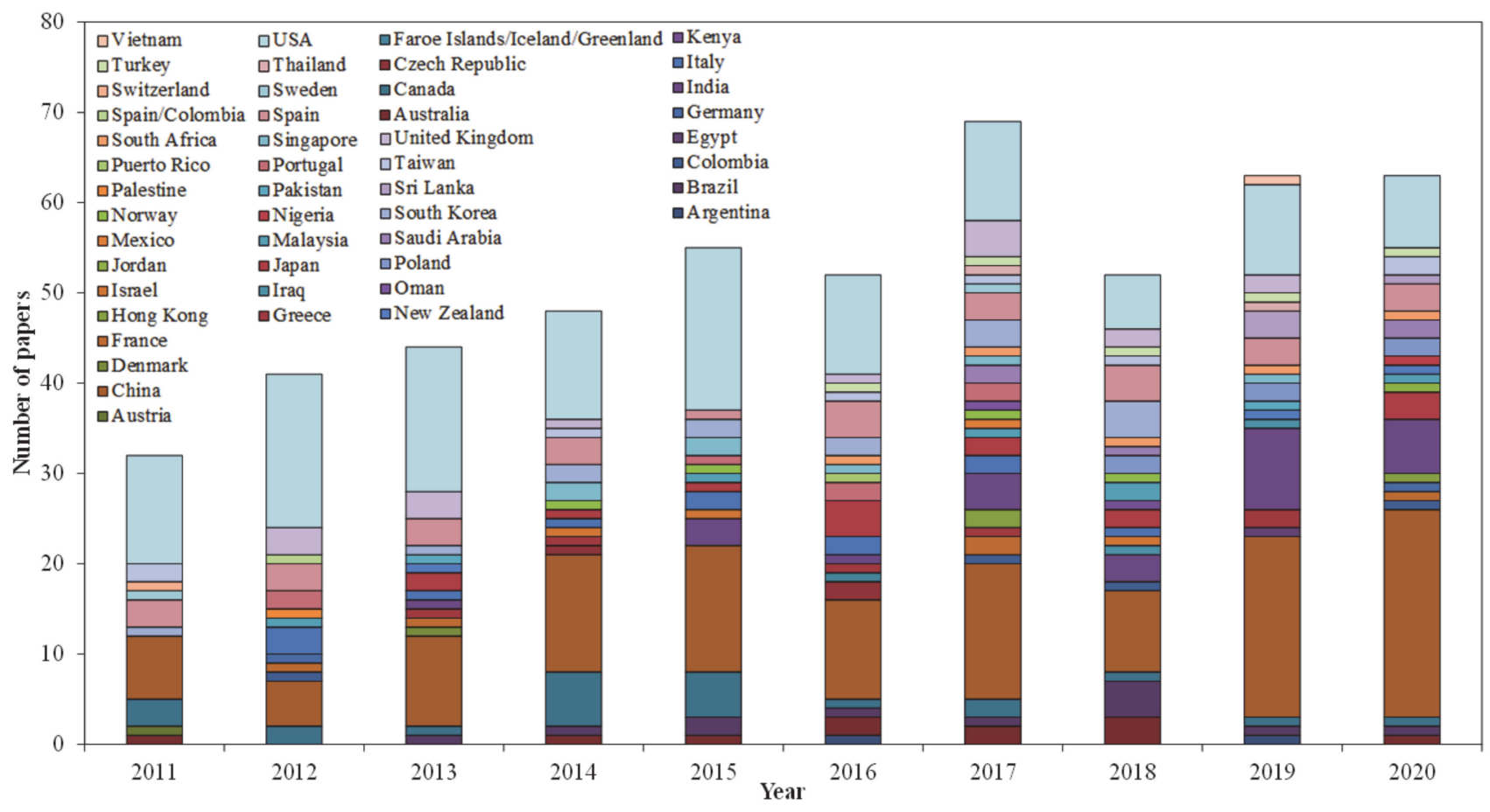

Figure 2. Number of published literature about PPCPs in different countries (2011 to 2020).

\subsection{Pathways and Occurrence of PРСР Compounds in Different Matrices}

There are more than 20,000 prescription drugs and approximately 1600 animal drug products approved by the US FOOD and Drug Administration (US FDA) as of 2020 [33]. Not all registered drugs were documented to be present in the environment due to analytical limitations and thus, the actual number of pharmaceutical compounds in different environmental compartments may be underestimated since the respective metabolites of these drugs were not yet accounted for [34]. From the downsized list of 133 studies containing PPCP data of real samples, 580 unique compounds were identified in different matrices. The frequently detected compounds in each matrix were summarized in Table 1. Despite the vast collection of PPCP compounds documented in analyzed samples, the exact number of compounds occurring in different media or environmental compartments 
is still unknown. The frequency of detection can serve as a basis for verifying the presence of or widespread occurrence of a known compound; however, it cannot be used as direct evidence that a specific compound is the most abundant or dominant in the environment since current studies only report pre-selected or targeted analytes. Ultimately, the frequency of detection can only be a basis for determining the persistence of a known compound in a specific type of sample.

Table 1. Reporting frequency of top five frequently detected PPCP compounds in different matrices.

\begin{tabular}{|c|c|c|}
\hline Matrix & Compound & Number of Times Reported \\
\hline \multirow{5}{*}{ Wastewater (raw/influent) } & Carbamazepine & 37 \\
\hline & Caffeine & 34 \\
\hline & Diclofenac & 31 \\
\hline & Ibuprofen & 29 \\
\hline & Acetaminophen & 28 \\
\hline \multirow{5}{*}{ Wastewater (effluent) } & Carbamazepine & 43 \\
\hline & Caffeine & 34 \\
\hline & Diclofenac & 34 \\
\hline & Sulfamethoxazole & 34 \\
\hline & Triclosan & 31 \\
\hline \multirow{5}{*}{ Surface water } & Carbamazepine & 50 \\
\hline & Caffeine & 43 \\
\hline & Diclofenac & 39 \\
\hline & Ibuprofen & 39 \\
\hline & Sulfamethoxazole & 37 \\
\hline \multirow{5}{*}{ Groundwater } & Caffeine & 6 \\
\hline & Carbamazepine & 5 \\
\hline & Diclofenac & 5 \\
\hline & DEET & 5 \\
\hline & Sulfamethoxazole & 4 \\
\hline \multirow{8}{*}{ Drinking water } & Caffeine & 8 \\
\hline & Ibuprofen & 5 \\
\hline & Sulfamethoxazole & 5 \\
\hline & DEET & 5 \\
\hline & Carbamazepine & 4 \\
\hline & Diclofenac & 4 \\
\hline & Naproxen & 4 \\
\hline & Clarithromycin & 4 \\
\hline \multirow{6}{*}{ Sediment/Soil } & Ibuprofen & 14 \\
\hline & Triclosan & 11 \\
\hline & Triclocarban & 11 \\
\hline & Caffeine & 10 \\
\hline & Diclofenac & 9 \\
\hline & Sulfamethoxazole & 9 \\
\hline \multirow{5}{*}{ Sludge/Biosolid } & Carbamazepine & 13 \\
\hline & Ibuprofen & 11 \\
\hline & Diclofenac & 10 \\
\hline & Triclosan & 10 \\
\hline & Propranolol & 9 \\
\hline
\end{tabular}


Table 1. Cont.

\begin{tabular}{ccc}
\hline Matrix & Compound & Number of Times Reported \\
\hline & Ibuprofen & 4 \\
& Caffeine & 3 \\
& BPA & 3 \\
& Diclofenac & 2 \\
& Acetaminophen & 2 \\
& Triclosan & 2 \\
& Naproxen & 2 \\
Plant & Triclocarban & 2 \\
& Bezafibrate & 2 \\
& Methylparaben & 2 \\
& Salicylic acid & 2 \\
& Ofloxacin & 2 \\
& Metformin & 2 \\
& Tramadol & 2 \\
& Atorvastatin & 2 \\
\hline Animal & Diphenhydramine & 10 \\
& Triclosan & 9 \\
& Sertraline & 9 \\
& Triclocarban & 8 \\
& Diclofenac & 7 \\
\hline
\end{tabular}

Note: DEET = N,N-Diethyl-meta-toluamide, BPA = Bisphenol A.

\subsubsection{Sources and Deposition Pathways of Frequently Detected PPCPs in Water}

The primary sources and modes of PPCP transport in water matrices are illustrated in Figure 3. Raw wastewater contains considerable amounts of PPCP compounds due to the continuous use or disposal of medications and healthcare products. Humans and animals cannot completely metabolize certain pharmaceuticals. In most cases, parent compounds and their respective metabolites are excreted in the body through the renal or biliary system $[35,36]$. The direct disposal of unused drugs can also be one of the pathways of pharmaceutical compounds into the sewer systems [37]. The compounds used as additives in personal care products and cosmetics are usually incorporated in wastewater through washing or bathing. Unlike pharmaceuticals, these products are typically used or applied externally and thus, simple washing or bathing can detach these compounds from the body [38].

Carbamazepine, caffeine, and diclofenac were the most frequently detected compounds in raw wastewater. Carbamazepine is an anticonvulsant or mood-stabilizing drug that primarily affects the central nervous system. The metabolism of carbamazepine in the human body can be variable. According to Doummar et al. (2014), the human body can metabolize $98 \%$ to $99 \%$ of carbamazepine and transform it to carbamazepine10,11-epoxide [39]. In another literature published by Hai et al. (2018), up to $10 \%$ of carbamazepine can be excreted from the human body after its consumption, leading to its widespread occurrence in wastewater [40]. Caffeine is a naturally occurring substance consumed by humans since ancient times. Caffeinated beverages such as coffee, tea, and energy drinks serve as the major source of caffeine in humans. In a study conducted in the United States, it was found that $85 \%$ of the surveyed population consumes a caffeinated beverage at least once per day, corresponding to an average daily caffeine intake of $165 \mathrm{mg}$ [41]. The frequent detection of caffeine in wastewater can be attributed to the washing of mugs containing residues of caffeinated drinks or the direct disposal of unconsumed caffeinated beverages in the drainage lines. Moreover, the incomplete metabolism of caffeine in the body can also incorporate trace amounts of caffeine in human excrements [42]. Diclofenac is recognized as the most commonly used pain killer and non-steroidal anti-inflammatory drug (NSAID), with an estimated annual consumption of 940 tons globally [43]. Similar to other pharmaceutical compounds, diclofenac (the metabolized and non-metabolized 
form) reaches the wastewaters through excretion. It was previously reported that $15 \%$ of diclofenac remains unchanged after consumption, thereby leading to its frequent detection in raw wastewaters [44].

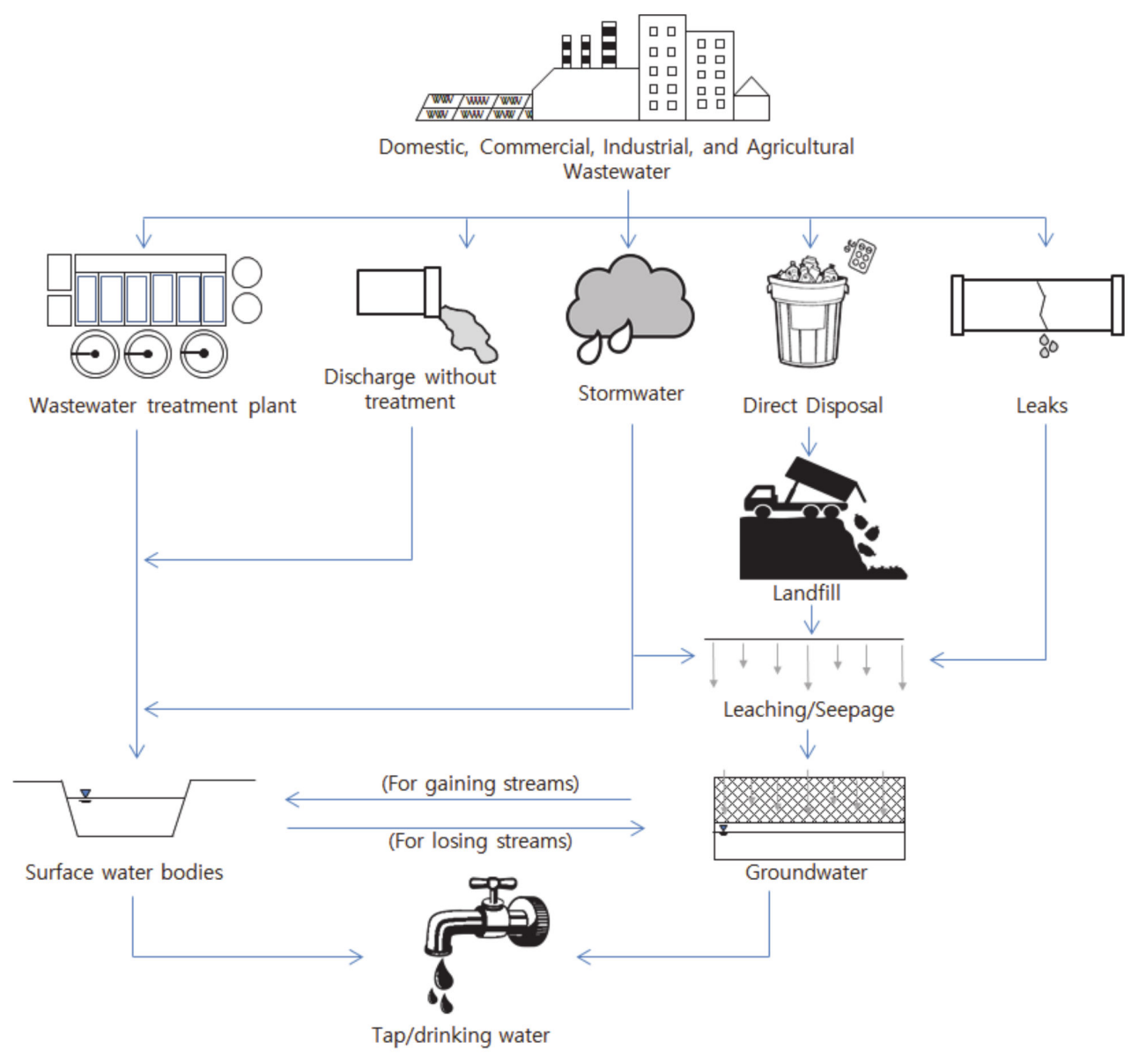

Figure 3. Sources and pathways of PPCPs on water matrices.

It has long been acknowledged that efficient wastewater treatment is essential to prevent water quality deterioration. Significant efforts have been made to improve sanitation and wastewater management all over the world in the past decades. In the year 1990, it was estimated half of the global population ( 5.3 billion people) had no access to improved sanitation services. This figure was reduced by more than half in the year 2015, wherein 2.4 billion people remain with no access to sanitation facilities. Despite the noticeable improvement in wastewater management, it was estimated that $80 \%$ of the globally produced wastewater is directly discharged into the environment without any treatment [45-47].

Wastewater treatment does not guarantee the complete elimination of PPCPs. Wastewater effluent contains trace amounts of recalcitrant PPCP compounds that cannot be removed by conventional treatment processes. In the compiled published literature, carbamazepine, caffeine, diclofenac, and sulfamethoxazole represent the most frequently detected compounds in treated wastewater. The frequent detection of caffeine, carbamazepine, and diclofenac in wastewater effluents can be related to their abundance in raw wastewaters. In the case of sulfamethoxazole, its high excretion rate among animals and humans resulted in its profound presence in wastewater. Sulfamethoxazole also belongs to the group of commonly used antibiotics for animal and human treatment [48]. Generally, all four compounds that are frequently detected in wastewater effluents were previously reported to be recalcitrant or partially degraded by conventional wastewater treatment techniques $[49,50]$. 
Water bodies are susceptible to PPCP contamination since natural waterways serve as the discharge point of sewer networks. Carbamazepine, caffeine, and diclofenac were also found to be the most commonly detected compounds reported in the published literature. Since wastewater is the primary route of PPCPs in the environment, the probability of detecting compounds present in wastewater on surface water bodies is also high. Apart from point sources, PPCP compounds can also reach the waterways by means of nonpoint source pollutant deposition. Masoner et al. (2019) reported the presence of different pharmaceutical compounds in stormwater runoff [51]. PPCP residues deposited on surfaces or leaks from sewer lines can either be incorporated in the stormwater runoff during rainfall events or seep through soil layers. The transport of PPCP compounds in the environment through non-point sources poses a more challenging concern as compared with point sources. Non-point pollution comes from diffuse sources, thus making it difficult to monitor all sorts of pollutants in stormwater.

About $98 \%$ of the world's natural freshwater resources are stored in groundwater reserves, making it a reliable source of drinking water in many regions around the globe [52]. As compared to surface water bodies, groundwater is less susceptible to contamination due to the soil layers that serve as natural pollutant filters; however, once contaminated, decontamination or cleanup is difficult to achieve due to its isolated nature. PPCP compounds from contaminated matrices (i.e., water, soil, and biosolids) can reach the water table through leaching. Compounds that have poor or selective sorption capabilities such as carbamazepine, caffeine, and diclofenac have greater tendencies to contaminate groundwater and exhibit frequent detection in the examined samples [53,54]. The number of studies regarding PPCP contamination in groundwater is scarce. Out of the 133 reviewed papers containing measured PPCP data, only seven articles reported the presence of PPCP compounds in groundwater samples. Based on this observation, it can be implied that the occurrence of PPCPs in groundwater is limited due to the natural filter layers protecting the reserves from being contaminated. Some studies noted the presence of PPCP compounds in groundwater; however, the majority of the analyzed compounds were below the instrument's limit of detection or quantification [55,56]. Another possibility for low groundwater PPCP data turnout is the lack of publications focusing on this topic, since there is evidence that the occurrence of PPCPs in groundwater is relatively scarce as compared with wastewaters and surface waters [57].

Drinking water undergoes stringent treatment to ensure the safety and well-being of the consumers. Drinking water treatment plants are equipped with mechanisms to eliminate typical pollutants in water (i.e., particulates, pathogens, etc.) but the recent discovery of PPCPs in raw water sources raised concerns on the effectiveness of conventional water treatment in removing these compounds. Several PPCP compounds (see Table 1) were detected in drinking water. The majority of the compounds reported in drinking water were also frequently detected in the raw water sources (i.e., caffeine, ibuprofen, sulfamethoxazole, DEET, carbamazepine, and diclofenac). In the year-long evaluation conducted by Padhye et al. (2014), it was concluded that most water treatment technologies were ineffective in removing PPCP compounds in the source water [58]. Residual PPCP concentrations were still found in the water after different stages of treatment, implying that certain compounds are resistant to degradation. Contrary to the findings presented by Padhye et al. (2014), Datel and Hrabankova (2020) reported that PPCP compounds responded well to the conventional water treatment technique [59]. Generally, the types and concentrations of PPCP compounds in drinking water are highly influenced by the raw water quality and the processes employed in the treatment plants.

\subsubsection{PPCP Routes in Soils, Sediments, and Biosolids}

As illustrated in Figure 4, two of the most common pathways of PPCP deposition in the terrestrial ecosystem are (1) irrigation using reclaimed wastewater and (2) the application of biosolids and wastewater treatment by-products in agricultural areas. Water scarcity is one of the most prominent global issues at present. Based on the global water data collected 
in the year 2019, a total of 44 countries around the world experience high to extremely high water stress [60]. The continuous increase in the global population and the growing water demand has resulted in the over-abstraction of natural water resources. Furthermore, climate change and water quality degradation has also imposed an additional burden on the availability of water resources.

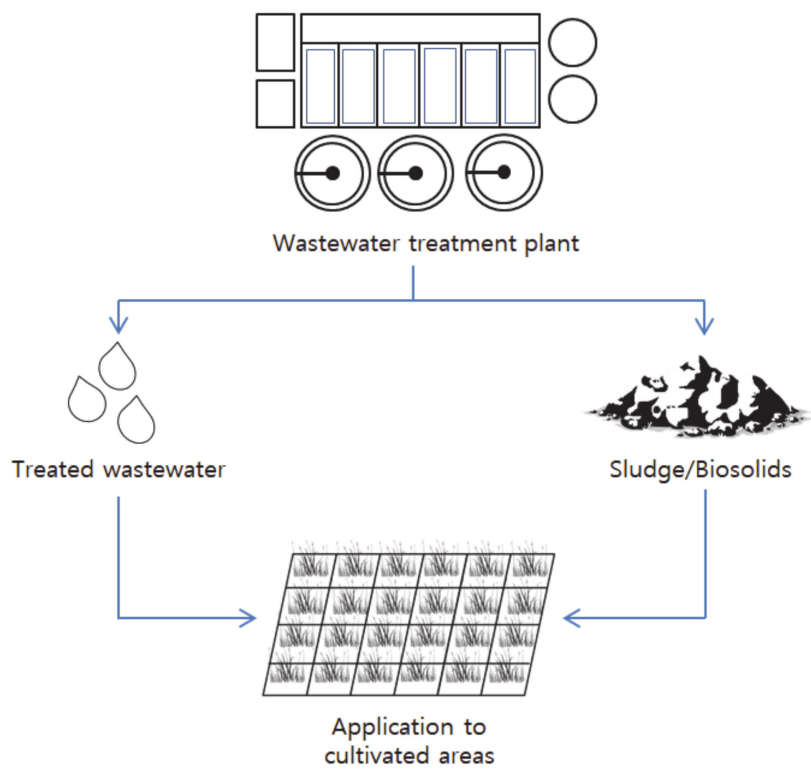

Figure 4. Deposition of PPCP compounds in the solid matrices.

The agricultural sector remains the highest water consumer in most countries, with an approximate global water withdrawal allocation of 70\% [61]. Over the years, water scarcity concerns have led to the extensive use of reclaimed wastewater for irrigation and other reuse applications. The concept of water reuse has also been widely applied for recreational and other non-potable urban applications in several developed nations. In the year 2004, 6400 million liters of water was reused in the United States per day, making it the country with the highest number of water reuse projects. Recent advancements in treatment technologies has enabled the reuse of wastewater for drinking purposes. Among the most successful potable reuse projects that are acknowledged globally include the United States' Orange County Groundwater Replenishment System and Singapore's NEWater [62,63]. Wastewater reuse has become a widely acceptable approach for relieving water stress in several regions around the world; however, recent investigations showed that the use of reclaimed wastewater for irrigation can lead to PPCP contamination in soils $[64,65]$.

Apart from using reclaimed water for irrigation, the application of biosolids and wastewater treatment by-products in agricultural lands can lead to the presence of PPCP compounds in the terrestrial ecosystem. Biosolids are commonly used as fertilizers due to their significant nutrient contents. In the European region alone, it was estimated that 39\% of the total sludge generated by the European Union member states in the year 2010 was recycled for agricultural applications [66]. The concept of reusing biosolids and wastewater treatment by-products as organic fertilizers was also recognized as a sustainable approach to reduce the use of chemical fertilizers and optimize the utilization of resources; however, immediate concerns were raised following the discovery of PPCP compounds in sludge.

The most commonly reported compounds detected in sludge and biosolids were carbamazepine, ibuprofen, and diclofenac. The presence of PPCPs in sludge is determined by the complex interaction among several factors such as raw wastewater concentration, wastewater treatment efficiency, and the properties of compounds [67]. Lipophilic substances or compounds with greater octanol/water partition coefficient $\left(\log \mathrm{K}_{\mathrm{OW}}\right)$ have greater affinities for organic matter, whereas hydrophilic compounds tend to evade sorption to sludge 
and suspended solids [68]. All three frequently reported compounds detected in sludge and biosolids were found to have low sorption potential, indicating a substantial deficit of studies regarding lipophilic compounds. Moreover, studies about the occurrence of PPCPs in sludge are relatively fewer as compared with wastewater due to the challenging methods of solids analysis [69].

The most frequently detected compounds in soils and sediments were ibuprofen, triclosan, and triclocarban. Ibuprofen is an over-the-counter NSAID commonly used as a pain reliever. In the year $2015,70 \%$ of the total ibuprofen purchases were made without prescription. Its frequent detection in different environmental matrices can be attributed to its widespread use in several countries around the world. Unlike ibuprofen, the production and use of triclosan and triclocarban were reduced greatly over the past years. The United States Food and Drug Administration (FDA) issued a rule in the year 2016 stating that these compounds were no longer considered as effective and safe ingredients for manufacturing personal care products [70]. Despite being phased out in big markets, triclocarban and triclosan persist in soils and sediments. Environmental conditions in agricultural areas (i.e., $\mathrm{pH}$, organic matter content of soil and temperature) can also affect the persistence of these compounds in soil [71].

\subsubsection{Frequently Detected PPCPs in Plants}

Plants utilize nutrients and minerals in soil or any planting media through the uptake process (see Figure 5). Alongside the essential compounds, potentially toxic substances can also be accumulated and translocated in different plant organs if the growing medium used is contaminated. The mechanisms of PPCP uptake by plants have been studied recently due to the potentially harmful effects of consuming contaminated products sold on markets [72]. Ibuprofen, caffeine, and BPA were among the compounds that were frequently detected in plant samples. The concentration and presence of PPCP compounds in plant tissues are greatly influenced by the chemical properties of PPCPs and plant structure. The review conducted by Al-Farsi et al. (2017) highlighted that PPCP transport in plants was mainly determined by the ability of the solute to cross membranes [73]. The primary pathways of PPCP transport in plant tissues can be apoplastic (movement of compounds between cells along the plant cell walls), symplastic (movement through microscopic channels known as plasmodesmata), or transmembrane (movement between cells through cell walls). PPCP compounds also undergo transformation processes in soil media as a factor of microbiological degradation. Compounds that are generally bioavailable for uptake present a greater tendency to be detected in plant tissues as compared with substances that have increased sorption in soils [74].

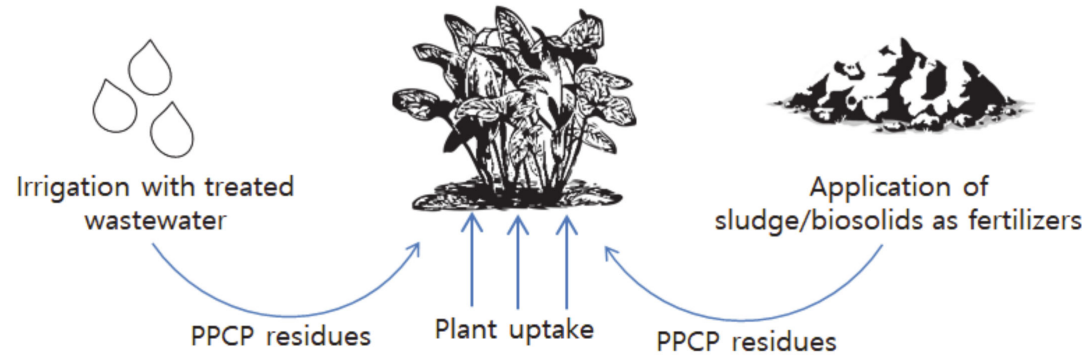

Figure 5. PPCP route in plants.

\subsubsection{Exposure of Aquatic and Terrestrial Animals to PPCP Compounds}

Aquatic organisms are susceptible to the adverse biological effects of PPCPs due to their constant exposure to these compounds. The exposure routes of animals and humans to PPCPs were illustrated in Figure 6. Wastewater-dominated streams are consistently dosed with pharmaceutically active and endocrine disrupting compounds as a result of the incomplete removal of PPCPs in wastewater. A number of studies verified the bioaccumulation of PPCP compounds in the plasma, tissues, and organs of aquatic animals [75-77]. 
Among the diverse suits of PPCPs in the aquatic system, diphenhydramine, triclosan, and sertraline were the most commonly reported compounds detected in fishes and bivalves. Aquatic organisms exhibit greater tendencies of bioaccumulating PPCP compounds due to their permeable bodies. The profound effects of PPCP exposure are mainly reflected in the reproductive traits of fishes and amphibians since their eggs do not have shell structures and amniotic membrane. Moreover, their eggs are commonly immersed in water, thus subjecting the embryos to contaminated water during the early stages of development [78].

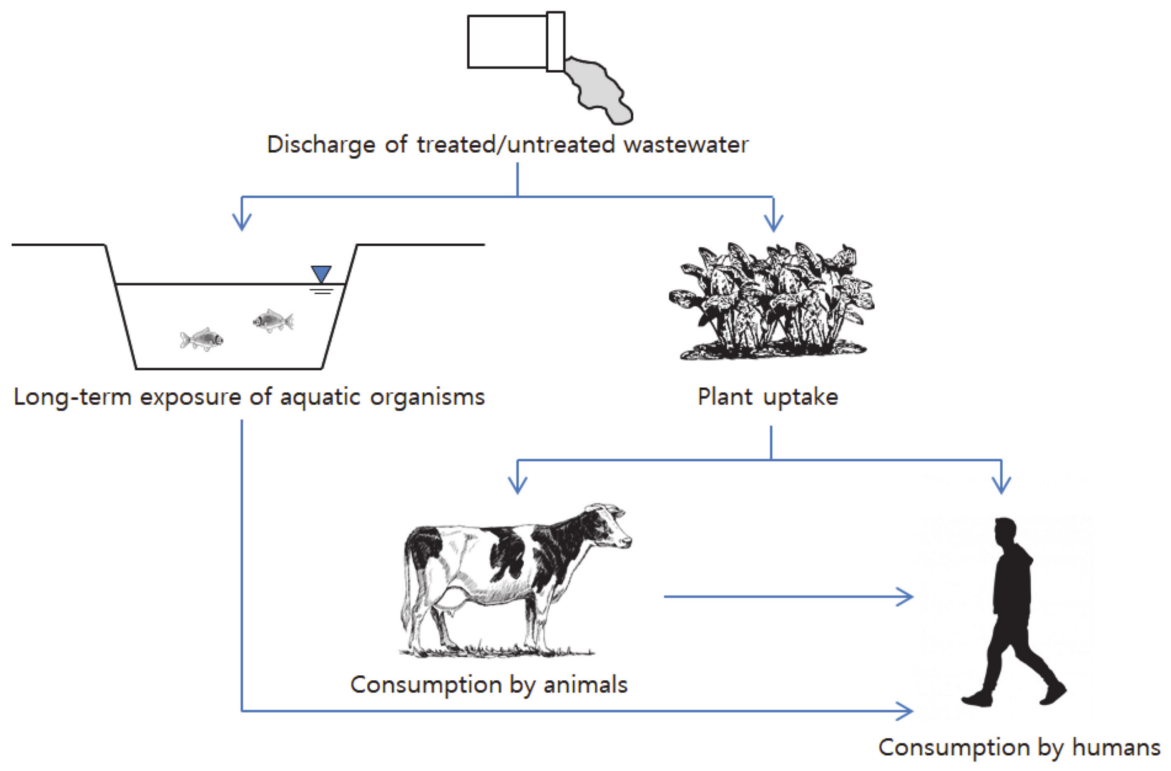

Figure 6. Exposure routes of animals and humans to PPCPs.

Veterinary medicines and hormones are usually employed in livestock industries to promote animal health and enhance reproduction. Terrestrial animals and humans can also be subjected to indirect PPCP exposure. The trophic transfer of PPCPs within the food web was identified as a potential route of indirect exposure of secondary and tertiary consumers to PPCP compounds; however, the possibility of trophic transfer and biomagnification potential of PPCPs within the food web remains unclear due to the inconsistencies in the findings from the different published literature. Earlier studies emphasized that lipophilic compounds that bioaccumulate on aquatic organisms can be transferred to higher-order animals and humans upon consumption $[79,80]$. Contrary to the previous reports, Lagesson et al. (2016) found that certain pharmaceutical compounds have weak trophic transfer potentials to top-consumers [81]. Overall, the PPCP residues are widely detected on animal tissues but there are still insufficient evidences regarding the trophic magnification of these compounds within the food web [8].

\subsection{Concentration of PPCP Compounds Reported in Different Countries \\ 3.3.1. PPCP Concentrations in Water}

The presence of PPCP compounds in wastewater, natural waterways, and other aqueous matrices are widely reported among different countries. The highest reported PPCP concentrations in water and wastewater from different countries were illustrated in Figure 7. Based on the compiled data from different publications, PPCP concentrations exhibited significant variations $(p<0.05$, coefficient of variation $(C V)=3.69)$. The highest PPCP concentration was reported by Peng et al. (2014) in China, wherein $4500 \mu \mathrm{g} / \mathrm{L}$ of BPA was detected in landfill leachates [82]. BPA has a wide range of applications in the industrial and manufacturing sectors. It is commonly used as a plasticizer, protective coating for food containers, and additives for manufacturing thermal paper [83]. In cosmetics, BPA serves as an antioxidant and product stabilizer $[84,85]$. There are relatively few manufacturers of BPA 
and BPA-based products in China but several companies produce electronics, automobiles, and other goods that utilize BPA-based raw materials [86].

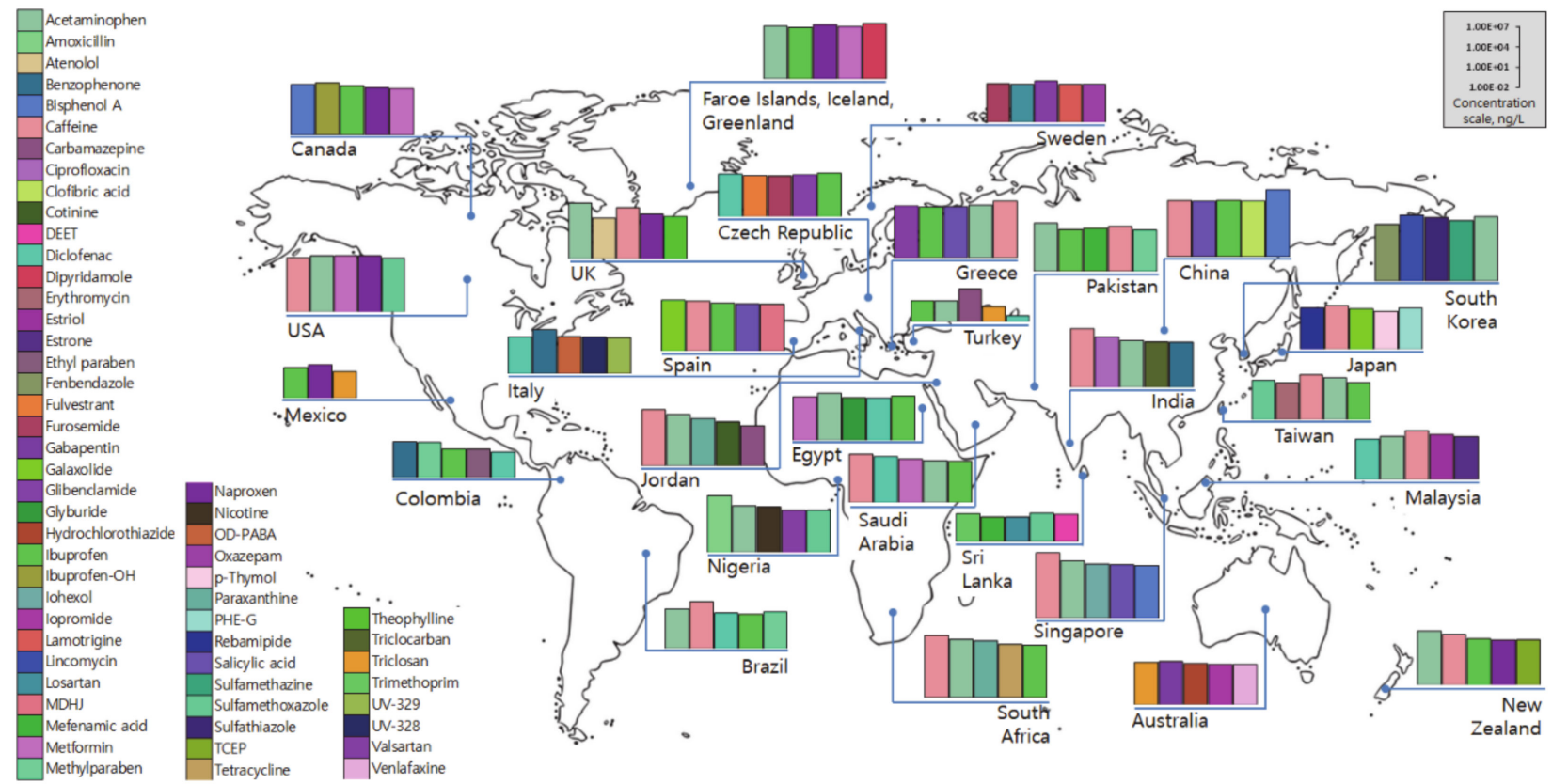

Figure 7. PPCP compounds with the highest detected concentrations in water samples. Note: $\mathrm{MDHJ}=$ methyl dihydrojasmonate, PHE-G = 2-Phenoxyethanol, TCEP = tris(2-carboxyethyl)phosphine, UV-328 = 2-(2H-Benzotriazol-2-yl)-4.6-di-tertpentylphenol, UV-329 = 2-(2H-Benzotriazol-2-yl)-4-(1.1.3.3-tetramethylbutyl) phenol.

Among Asian countries, the majority of high PPCP concentrations were detected in raw wastewaters (1353 ng/L to $3854 \mu \mathrm{g} / \mathrm{L}$ ) and surface water bodies ( $35 \mathrm{ng} / \mathrm{L}$ to $42 \mu \mathrm{g} / \mathrm{L}$ ). Caffeine was found to be the most commonly reported compounds that have remarkably high concentrations in different water matrices. In the study conducted by Tran et al. (2014), up to $3594 \mu \mathrm{g} / \mathrm{L}$ of caffeine was detected in a raw wastewater sample in Singapore [55]. A considerably high concentration of caffeine $(499 \mu \mathrm{g} / \mathrm{L})$ in a raw wastewater sample from India was also reported by Archana et al. (2017) [87]. Both studies cited lifestyle or patterns of consumption as the primary cause of the high detection of caffeine in wastewater. Caffeine concentrations in surface water bodies were relatively lower as compared with the detected concentrations in wastewater. Tamura et al. (2017) reported a measured caffeine concentration of $5330 \mathrm{ng} / \mathrm{L}$ in Japanese streams, whereas Picó et al. (2020) quantified approximately $21 \mu \mathrm{g} / \mathrm{L}$ of caffeine from an irrigation water source in Saudi Arabia [88,89]. Generally, the natural purification mechanisms of rivers and flowing waterways can also lead to a lower concentration of PPCP compounds in natural water bodies.

In the Australasian region, acetaminophen had the highest concentration among the reported PPCP compounds. Kumar (2020) identified that $118 \mu \mathrm{g} / \mathrm{L}$ of acetaminophen was present in a wastewater sample from New Zealand [90]. It was also indicated that acetaminophen was among the list of frequently prescribed medicines in New Zealand, thereby resulting in the high concentration of this compound in wastewater. The highest concentrations of PPCP compounds ( $5 \mathrm{ng} / \mathrm{L}$ to $221 \mu \mathrm{g} / \mathrm{L}$ ) in European countries were mostly detected on raw wastewater. The three compounds with the highest concentrations were caffeine $(221 \mu \mathrm{g} / \mathrm{L})$, followed by dipyridamole $(166 \mu \mathrm{g} / \mathrm{L})$, and acetaminophen $(158 \mu \mathrm{g} / \mathrm{L})$. Apart from pharmaceuticals, chemical additives for personal care products were also detected at high concentrations in European surface waters. Mandaric et al. (2017) identified the seasonal patterns of selected PPCPs in the Alpine rivers of Italy [91]. Ultraviolet (UV) filters octyl-dimethyl-p-aminobenzoic acid (OD-PABA) and benzophenone were detected in river water samples at concentrations up to $748 \mathrm{ng} / \mathrm{L}$ and $5720 \mathrm{ng} / \mathrm{L}$, respectively. It was also highlighted that PPCP detection frequencies and concentrations 
were highly influenced by anthropogenic activities and seasonal variations affecting the dilution of pollutants in surface water bodies. Caffeine $(1214 \mu \mathrm{g} / \mathrm{L})$ and acetaminophen $(343 \mu \mathrm{g} / \mathrm{L})$ were also found to have the highest concentrations in the African continent. Traces of nicotine $(9335 \mathrm{ng} / \mathrm{L})$ in a surface water sample from Nigeria were also reported by Ebele et al. (2020) due to the presence of tobacco farms in the sampling sites [92]. Generally, it can be implied that land-use and non-point sources of pollution can significantly affect the deposition of PPCP compounds in the environment.

Over-the-counter medications, such as acetaminophen $(218 \mu \mathrm{g} / \mathrm{L})$ and naproxen $(210 \mu \mathrm{g} / \mathrm{L})$, and the prescription drug metformin $(211 \mu \mathrm{g} / \mathrm{L})$ found in raw wastewaters had the highest concentration in the Americas. Acetaminophen and naproxen were among the most commonly used NSAIDs in the United States, whereas the use of metformin as an anti-diabetic drug was also prevalent in the region [93,94]. Evidences of high PPCP concentrations in surface water bodies were also extensively reported in the South American region. The concentrations of caffeine, acetaminophen, and methylparaben in a Brazilian river system reported by Chaves et al. (2020) amounted to $13 \mu \mathrm{g} / \mathrm{L}, 1716 \mathrm{ng} / \mathrm{L}$, and $660 \mathrm{ng} / \mathrm{L}$, respectively [95]. Aristizabal-Ciro et al. (2017) also reported the existence of persistent PPCP compounds in the tributary rivers draining into drinking water reservoirs in Colombia [96]. The occurrence of benzophenone (502 ng/L), methylparaben ( $425 \mathrm{ng} / \mathrm{L})$, and ibuprofen $(62 \mathrm{ng} / \mathrm{L})$ in the tributaries was found to be the main source of PPCP compounds in the drinking water source. Moreover, trace concentrations $(7 \mathrm{ng} / \mathrm{L}$ to $80 \mathrm{ng} / \mathrm{L})$ of PPCP compounds were also detected in finished drinking water, indicating that the treatment technology used was inefficient in removing polar contaminants.

\subsubsection{Accumulation of PPCP compounds in soils, sediments, sludge, and biosolids}

The highest reported PPCP concentrations in solid matrices are exhibited in Figure 8. The mean concentration of PPCP compounds detected in sludge and biosolids $(32.7 \pm 116.9 \mu \mathrm{g} / \mathrm{g})$ was over 27 times higher than the average value reported for soils and sediments $(1.2 \pm 2.3 \mu \mathrm{g} / \mathrm{g})$. Moreover, greater variations in PPCP concentrations were observed in sludge and biosolids samples $(\mathrm{CV}=2.7)$ as compared with soils and sediments $(\mathrm{CV}=1.3)$. The highest PPCP concentration in sludge was detected from a wastewater treatment plant in Hveragerdi, Iceland. Huber et al. (2016) noted that the high concentration of cetrimonium salt $(680 \mu \mathrm{g} / \mathrm{g})$ found in the sludge from an Icelandic wastewater treatment plant implied that sludge could act as sinks of PPCPs in wastewater [97]. Antibiotics norfloxacin and ciprofloxacin were among the compounds with the highest detected concentration in soils and sediments. Ashfaq et al. (2019) reported norfloxacin and ciprofloxacin concentrations of up to $6490 \mathrm{ng} / \mathrm{g}$ and $6050 \mathrm{ng} / \mathrm{g}$, respectively, in the sediment samples collected from an urban drain [98]. The abundance of antibiotic residues detected in the sediments was attributed to the complex adsorptive properties of these compounds, which resulted in a greater sediment partitioning.

In Asia, Europe, and American regions, antibiotic compounds were commonly detected at elevated concentrations in solid matrices. A maximum concentration of 20,600 ng/g of norfloxacin was detected by Wang et al. (2018) in sludge samples from China, whereas Narumiya et al. (2013) reported a high triclosan concentration $(14,500 \mathrm{ng} / \mathrm{g}$ ) in sludge alongside other fluoroquinolone antibiotics $[99,100]$. Despite its short half-life ( $<80$ days) and infrequent detection, high doxycycline concentration $(187 \mu \mathrm{g} / \mathrm{g})$ was observed in the solid-phase pig slurry from a livestock farm in France. It was also noted that doxycycline was strongly sorbed in solids due to its high solid/liquid partition coefficient $\left(\log \mathrm{K}_{\mathrm{d}}=3.2 \mathrm{~L} / \mathrm{kg}\right)$ in slurry. Other fluoroquinolone antibiotics, such as ofloxacin $(4601 \mathrm{ng} / \mathrm{g})$ and ciprofloxacin (3959 ng/g), were also among the compounds with the highest concentrations in the European region [101]. The concentrations of triclosan (9322 ng/g) and ciprofloxacin $(3438 \mathrm{ng} / \mathrm{g}$ ) in biosolids reported by Brown et al. (2019) were found to be the highest in the American region [102]. Overall, the widespread occurrence of PPCP compounds in solid matrices was verified in several countries around the world. 


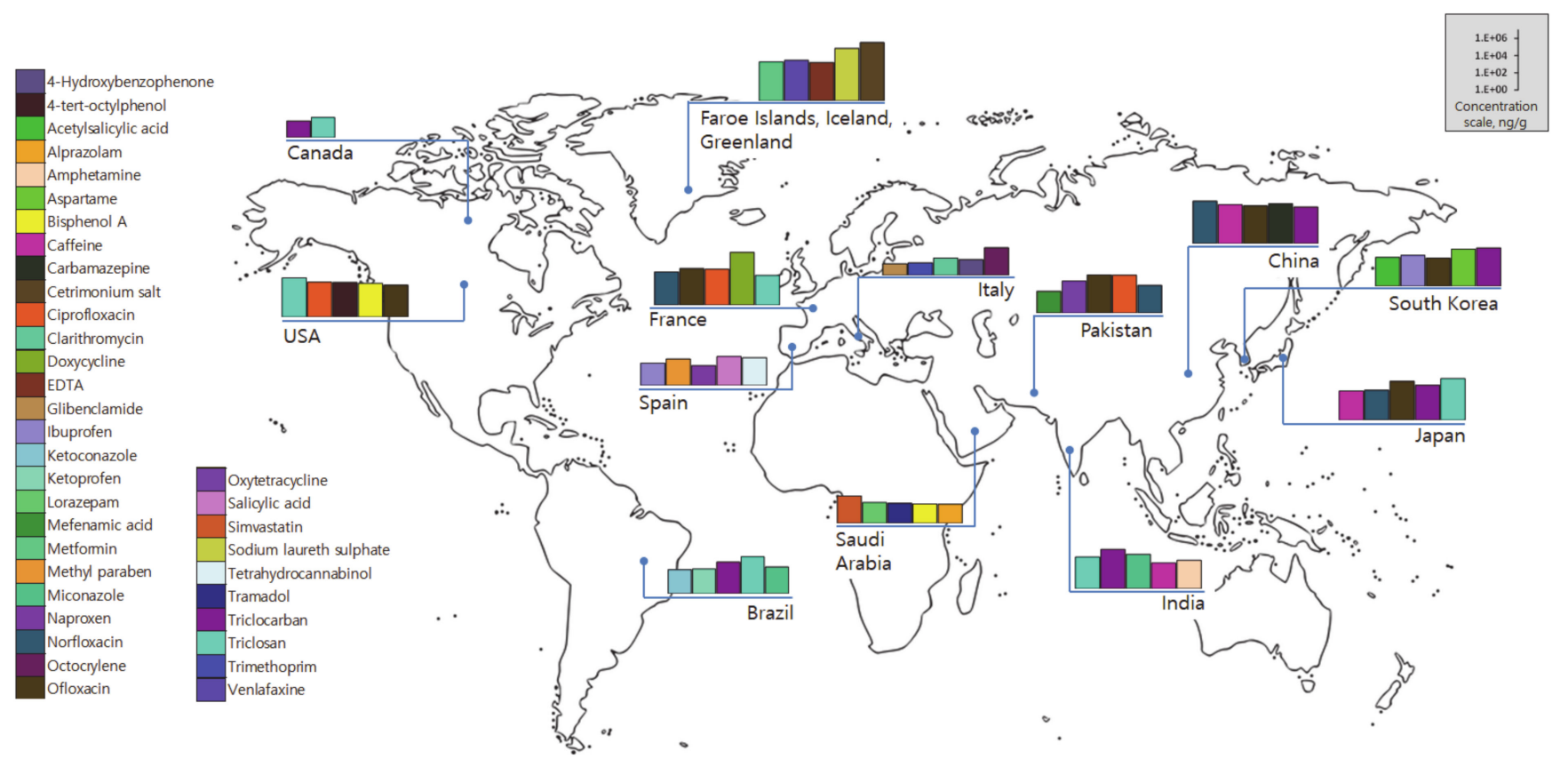

Figure 8. PPCP compounds with the highest detected concentrations in solid matrices.

\subsubsection{Plant Uptake and PPCP Concentrations in Plant Tissues}

Studies regarding the uptake of PPCPs by plants in the environmental setting are scarce. The majority of investigations concerned with the capabilities of plants to uptake PPCP compounds are usually conducted using a controlled environment or semi-field conditions [103-105]. The highest concentrations of PPCP compounds detected in field plant samples are presented in Figure 9. Liu et al. (2020c) investigated the levels of PPCP uptake among the plants grown in an agricultural system in China irrigated by reclaimed wastewater. Among the studied compounds, N4-acetyl-sulfamethoxazole (96 ng/g), sulfisoxazole $(24 \mathrm{ng} / \mathrm{g})$, and triclosan $(18 \mathrm{ng} / \mathrm{g})$ had the highest concentrations detected in different crops [106]. The variations in the uptake and translocation characteristics exhibited by plants were attributed to the interaction among the physicochemical and biological properties of the plants, soil, and PPCPs. Moreover, it was also reported that the accumulation of PPCP compounds in the planting had a greater influence on plant uptake as compared with the duration of irrigation. The occurrence of PPCP compounds in the tissues of wild plants growing on Arabian lakeshores and waterways was studied by Picó et al. (2020) [89]. Salicylic acid, methylparaben, and ibuprofen with concentrations amounting to $1952 \mathrm{ng} / \mathrm{g}, 614 \mathrm{ng} / \mathrm{g}$, and $135 \mathrm{ng} / \mathrm{g}$ were found to have remarkable presence in plant tissues. Constructed wetlands (CWs) are widely applied as secondary or tertiary treatment facilities for polishing wastewater effluent. In the study conducted by Wang et al. (2019), the accumulation of PPCP compounds in the tissues of Typha angustifolia planted in a CW system in Singapore was quantified to evaluate their phytoremediation capabilities [107]. Caffeine (2091 ng/g), BPA ( $25 \mathrm{ng} / \mathrm{g})$, and ibuprofen (12 ng/g) alongside other PPCP compounds were successfully accumulated in the plant tissues. High bioconcentration factors, ranging from 60 to 2000, also indicated that Typha angustifolia is capable of treating PPCP compounds in water through phytoremediation.

\subsubsection{Bioaccumulation of PPCP Compounds in Animal Organs}

Broad investigations and in vivo studies were conducted in different countries to determine the potential effects of PPCP bioaccumulation among different organisms. As exhibited in Figure 10, various compounds were detected in animal samples that were exposed to environmental PPCP concentrations. The highest PPCP concentration was observed by Subedi et al. (2012), wherein 12,000 ng/g of galaxolide was detected in 
the tissues of a fish sample collected from a German river system [108]. Galaxolide is a polycyclic musk commonly used in fragrances. Aside from the high production and consumption of galaxolide in Germany, this compound has a large bioconcentration factor (1584), high $\log \mathrm{K}_{\mathrm{OW}}$ value (5.9), and high resistance to degradation processes. Fussel et al. (2014) also reported the prevalence of personal care product additives in the fish samples from the United Kingdom [109]. Galaxolide (50.3 ng/g) and tonalide (34.3 ng/g) were found to have the highest concentrations among the PPCP compounds tested in the fish samples, indicating that these personal care product additives are bioaccumulative. NSAIDs ketoprofen $(2208 \mathrm{ng} / \mathrm{g}$ ) and ibuprofen $(562 \mathrm{ng} / \mathrm{g})$ were detected at high concentrations in the biota samples from China (Xie et al., 2019), whereas the antibiotic triclosan $(906 \mathrm{ng} / \mathrm{g})$ had the highest concentration measured in the liver of the fish sample from Japan (Tanoue et al., 2015) [26,110]. De Solla et al. (2016) studied the body burdens imposed by PPCP compounds on caged and wild mussel samples from Canada [111]. Out of the 43 pharmaceutical compounds detected on mussel tissues, dimethylxanthine was found to have the highest concentration $(803 \mathrm{ng} / \mathrm{g})$.

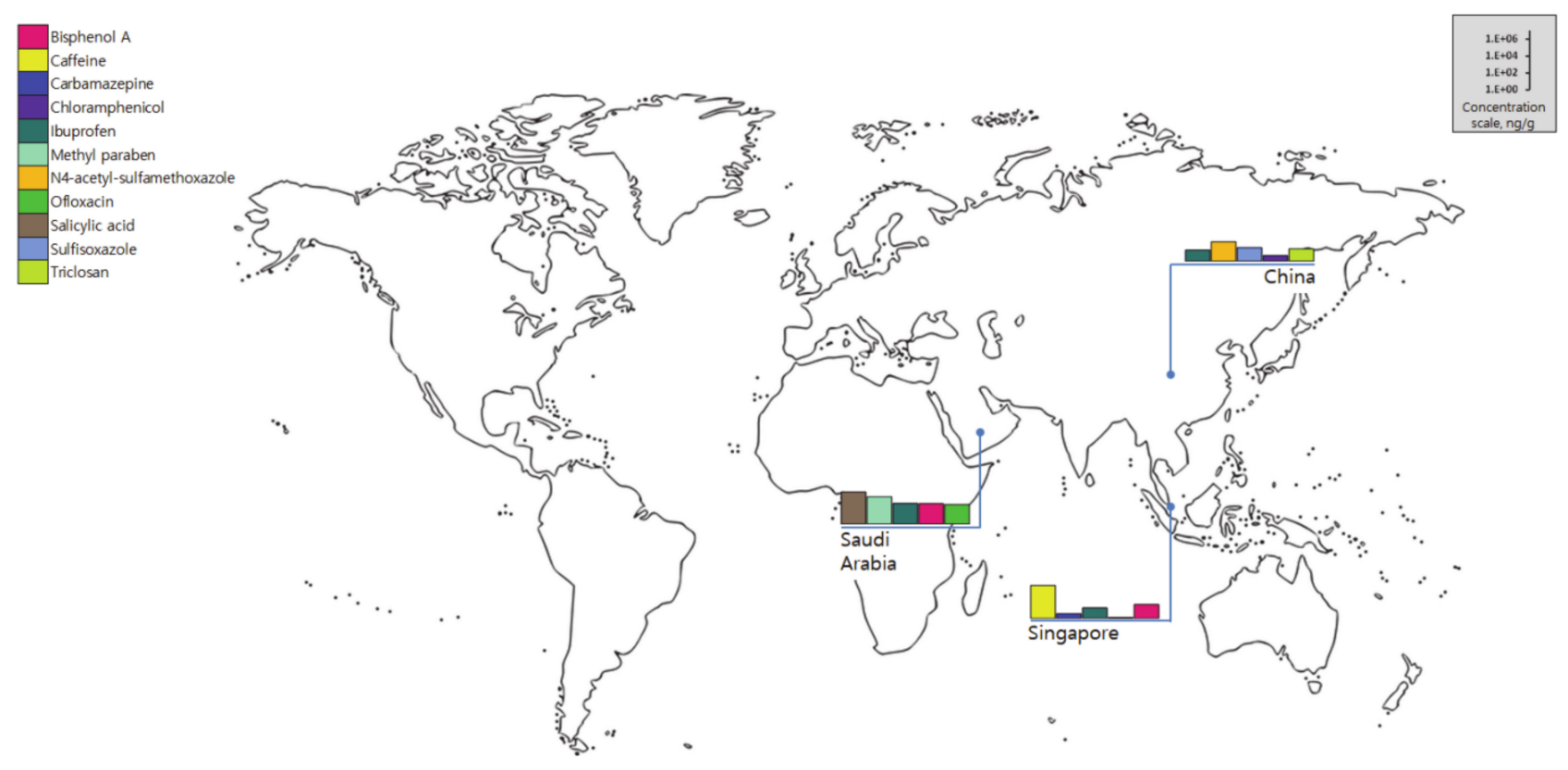

Figure 9. PPCP compounds with the highest detected concentrations in plant tissues.

The ecotoxicity of PPCP compounds remains one of the biggest knowledge gaps in PPCP research. While numerous studies regarding the toxic properties, lethal effects, and endocrine-disrupting potentials of PPCP compounds have been carried out globally, there are no generic conclusions regarding the negative effects of PPCPs that is applicable on all organisms [112-119]. Pharmaceuticals can have beneficial effects on humans, but these compounds can have adverse effects on non-target organisms exposed even at low concentrations. Gonzalez-Rey and Bebianno (2012) reported that certain mussel species (M. galloprovincialis) exposed to a realistic environmental concentration of ibuprofen ( $250 \mathrm{ng} / \mathrm{L}$ ) experienced endocrine-disrupting effects and digestive membrane damage [120]. Acetaminophen and caffeine were among the most commonly detected PPCP compounds occurring at high concentrations in different matrices. Despite the relatively high frequency of detection and concentrations, some studies indicated that these compounds pose low risks to aquatic organisms. Escapa et al. (2019) reported that exposure to high concentrations of acetaminophen ( $25 \mu \mathrm{g} / \mathrm{L}$ to $25,000 \mu \mathrm{g} / \mathrm{L})$ did not cause any effects on the mortality of zebrafish embryos at different stages of development [121]. A low profile of toxicity was also observed by Capolupo et al. (2016) on mussels (Mytilus galloprovincialis L.) exposed at different concentrations of caffeine ( $5 \mathrm{ng} / \mathrm{L}$ to $500 \mathrm{ng} / \mathrm{L}$ ) [122]. Despite the observed 
alterations in the biological processes and the onset of stress syndromes in the mussel samples, it was concluded that caffeine induced low environmental risks. Generally, the molecular and functional effects of PPCP compounds may vary from species to species [16].

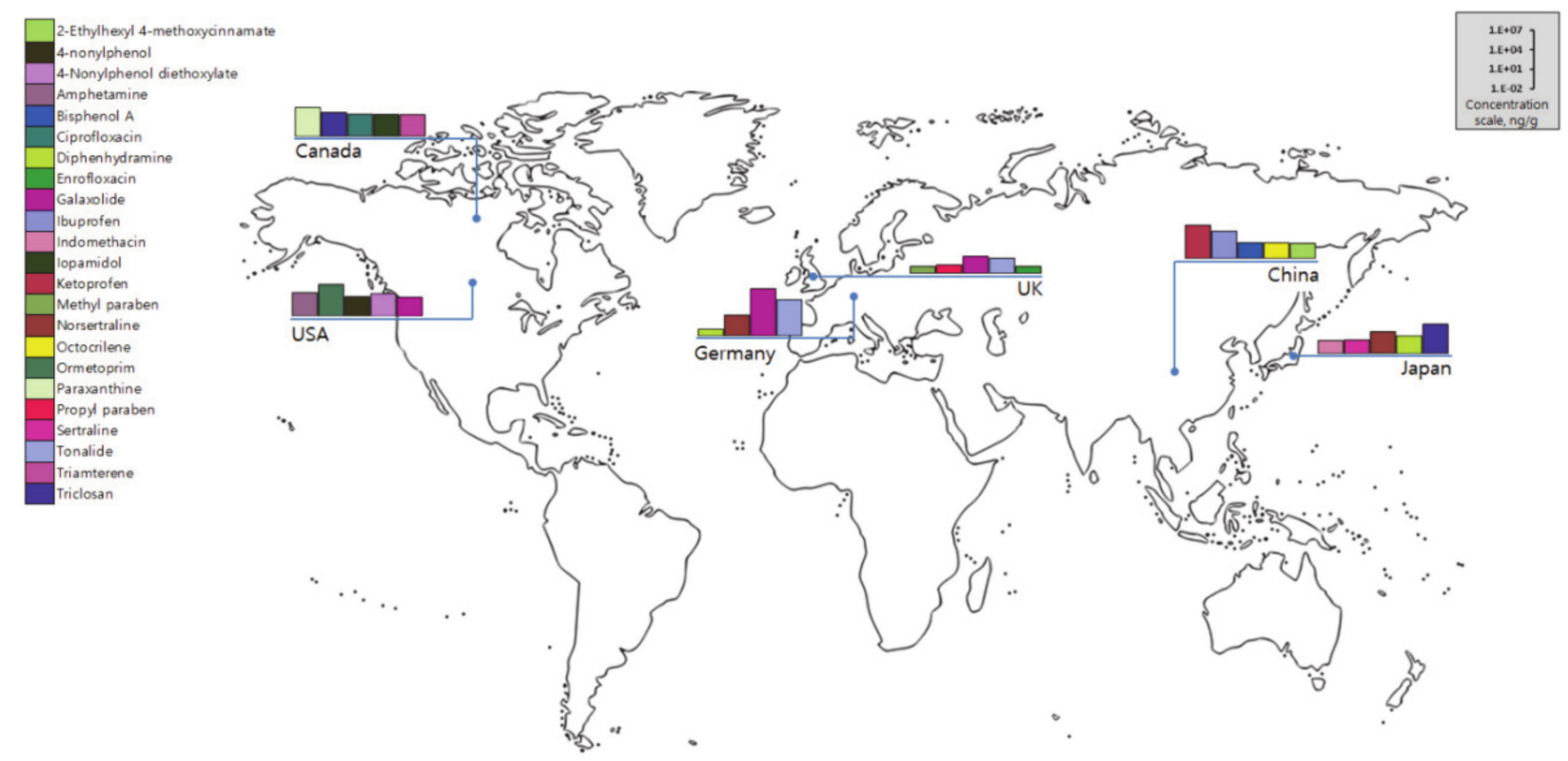

Figure 10. Concentrations of PPCP compounds in animal tissues and organs.

\subsection{Treatment Technologies for the Removal of PPCPs}

A number of factors (i.e., financial constraints, location, service population, etc.) are considered in the selection of the most applicable wastewater treatment technology for a specific location. Among the selection criteria, the influent water composition and pollutant concentrations are among the most important parameters since the treatment process mainly depends on the target pollutant removal efficiency. The majority of the water and wastewater treatment processes are not designed to eliminate PPCPs in water. Advanced treatment technologies were reported to have enhanced PPCP removal capabilities, but even tertiary treatment systems may not be sufficient to achieve the complete removal of PPCP compounds [123]. The PPCP removal efficiency of different treatment technologies utilized for water and wastewater treatment was summarized in Table 2. Most treatment processes reported removal efficiencies of up to $100 \%$, but negative values indicated that some PPCP compounds exhibited greater concentrations after receiving treatment.

Compounds such as acetaminophen, caffeine, and bezafibrate were successfully eliminated using the conventional activated sludge (CAS) process. Caffeine and bezafibrate were previously reported to be easily degradable in the activated sludge process $[124,125]$. The effective removal of acetaminophen was attributed to the prevalence of electron-donating groups. Specifically, the phenolic compounds present in acetaminophen enabled its full oxidation through oxidoreductase enzymes from microorganisms [126]. Membrane bioreactor (MBR) and bardenpho systems also exhibited the effective removal of different PPCP compounds. Kumar et al. (2019) reported that MBR and bardenpho systems had no significant difference $(<10 \%)$ in PPCP removal performance [127]. Moreover, the overall treatment efficiencies of the two systems ranged from $90 \%$ to $97 \%$ in all four seasons. Large differences in the removal efficiency of PPCPs were observed by Pai et al. (2020) in a conventional water treatment plant [128]. Relatively high removal was observed for oxybenzone (95.2\%), whereas other examined compounds exhibited low removal $(<75 \%)$ due to the low concentrations of PPCPs in the source water. Padhye et al., 2014 investigated the PPCP removal capability of the different treatment units in a drinking water treatment plant [58]. It was found that the conventional multi-barrier system contributed $>75 \%$ of 
the total PPCP removal. Moreover, it was also concluded that employing ozonation in the treatment process can enhance the removal of various PPCP compounds in water.

The application of photocatalysis and ozonation has been known to efficiently remove organic compounds, such as PPCPs, in wastewater. Heterogeneous photocatalysis has shown a potential to transform or degrade PPCPs without any harmful by-products; however, its low oxidation rates can lead to low mineralization. While ozonation can be effective in treating wastewater with high organic compounds concentration, ozone recalcitrant by-products may also result to low rates of mineralization $[129,130]$. In order to address the limitations of photocatalysis and ozonation, the combination of these two processes, known as photocatalytic ozonation, was recently employed to achieve greater efficiencies in terms of organic pollutant removal. The synergy between the two oxidation processes enhances the generation of $\mathrm{OH}$ radicals and the effective utilization of oxidants [131]. Aguinaco et al. (2012) studied the effectiveness of photocatalytic oxidation in the removal of diclofenac from secondary wastewater effluent. The system which utilized $\mathrm{TiO}_{2}$ catalyst exhibited the complete elimination of diclofenac within six minutes of operation [132]. The solar $\mathrm{TiO}_{2}$ photocatalytic ozonation employed by Márquez et al. (2014) in the treatment of wastewater also showed excellent removal of organic compounds. Apart from the efficient mineralization of organic compounds $(\sim 85 \%)$, the process resulted in high toxicity removal $(\sim 90 \%)$ and the efficient use of ozone [133]. Using the SnO2@ZnS photocatalyst, Hojamberdiev et al. (2020) demonstrated the detailed pathways of PPCP removal in an aqueous solution. It was observed that photocatalytic processes are more dominant pathways of removing PPCPs as compared with adsorption. It was also identified that triclosan and metoprolol had better adsorption affinities than carbamazepine and acetaminophen [134].

Adsorption techniques increasingly utilized in the removal of PPCP compounds from wastewater. As compared to membrane and advanced oxidation processes, PPCP removal through adsorption requires less energy consumption and does not produce harmful byproducts. Activated carbon is the most common type of adsorbent used in the process but other low-cost adsorbents (i.e., natural clay minerals, zeolite, and goethites) have also been studied [135,136]. Yi et al. (2020) demonstrated the effects of the hydraulic retention time and the length of the adsorbent layer on the treatment of PPCPs. The combination of granular activated carbon (GAC) and a biodegradable polymer (poly-3-hydroxybutyrateco-hydroxyvalerate) effectively reduced the metorprolol and diclofenac concentration by up to $80 \%$. It was also noted that increasing the length of the GAC layer and HRT can lead to higher or complete removal of PPCPs [137]. Adsorption can also be used as a supplementary process to further improve wastewater treatment. In the study conducted by Rodriguez et al. (2016), the activated carbon adsorption process was used in conjunction with ultrafiltration (UF) to improve the PPCP removal performance of the system. Incorporating the adsorption process substantially increased the removal of less hydrophobic compounds such as benzotriazole, DEET, and nortriptyline were observed. Ultimately, it was identified that the compound's hydrophobicity and charge and the adsorbent's adsorption capacity were the primary factors that influenced the removal of organic micropollutants [138].

Advanced treatment facilities usually incur additional operational and construction costs, making it impractical for small-scale applications. Recent advances in treatment technologies utilize nature-based solutions (NBS) as cost-efficient alternatives to advanced treatment facilities. CW is a type of nature-based facility that is used as a secondary or tertiary treatment of wastewater due to its ability to effectively remove pollutants $[139,140]$. In order to determine the effectiveness of CWs in treating PPCPs, Wang et al. (2019) conducted a study about the behavior and distribution of PPCP compounds in a full-scale CW system [107]. It was reported that CWs contributed to the removal of PPCPs through the uptake of plants and the microbial degradation of compounds in the reed beds. The majority of the removal took place in the equalization tank, wherein dilution with surface water was employed. Overall, studies regarding the applicability of NBS for PPCPs remain 
scarce, and the mechanisms for the effective removal of PPCPs in nature-based systems are still lacking.

Several occasions of negative PPCP removal were observed from different studies (see Table 2). Among the studied compounds, carbamazepine exhibited greater tendencies to have negative removals in various treatment systems. Several studies reported the poor removal of carbamazepine due to its poor biodegradability, birefractory nature, and low sorption to sludge [141-143]. Negative mass balances can also be attributed to the retransformation of conjugates to parent compounds, desorption from sludge, and the release of PPCPs from fecal matter degraded by microorganisms [144]. Due to the complex transformation patterns and degradation mechanisms of PPCPs, a strategic selection method is necessary to achieve the efficient removal of these compounds in water and wastewater.

Table 2. PPCP removal efficiencies of different treatment processes.

\begin{tabular}{|c|c|c|c|c|c|}
\hline \multirow{2}{*}{ Country } & \multirow{2}{*}{ Type } & \multicolumn{2}{|c|}{ Removal Efficiency, \% } & \multirow{2}{*}{ Process/Advanced Treatment/System } & \multirow{2}{*}{ Reference } \\
\hline & & Min & Max & & \\
\hline Taiwan & Drinking Water & 10.1 & 95.2 & Conventional water treatment & [128] \\
\hline Singapore & Wastewater & -1777 & 99.9 & $\mathrm{CW}$ & [107] \\
\hline New Zealand & Wastewater & 12 & 100 & MBR & \\
\hline New Zealand & Wastewater & 16 & 100 & Bardenpho & [127] \\
\hline China & Wastewater & -193 & 99.7 & CAS & [99] \\
\hline Singapore & Wastewater & -53.7 & 100 & CAS & \\
\hline Singapore & Wastewater & -80.7 & 100 & MBR & [126] \\
\hline Germany & Wastewater & 40 & 70 & Photocatalysis and adsorption & [134] \\
\hline China & Wastewater & 0.5 & 100 & Filtration and adsorption & [137] \\
\hline Spain & Wastewater & 13 & $>95$ & UF & \\
\hline Spain & Wastewater & $>60$ & 100 & UF + Adsorption & [138] \\
\hline South Korea & Wastewater & -58 & 99.9 & Symbio ${ }^{\circledR}$ & \\
\hline South Korea & Wastewater & -64.4 & 100 & 5-stage BNR & [145] \\
\hline China & Wastewater & -2 & 100 & MBR & [146] \\
\hline United Kingdom & Wastewater & -890 & 100 & CAS & \\
\hline United Kingdom & Wastewater & -1150 & 99 & Trickling filter & [147] \\
\hline Malaysia & Wastewater & 35.7 & 99.5 & Intermittent Decanting Extended Aeration & [148] \\
\hline China & Wastewater & -37.7 & 99.6 & Secondary biological treatment & [149] \\
\hline United States & Drinking Water & 21 & 98.2 & Conventional water treatment with Ozonation & [58] \\
\hline Canada & Wastewater & -99.8 & 98.9 & Sewage lagoon $\mathrm{w} / \mathrm{UV}$ & [143] \\
\hline China & Wastewater & 67 & 87 & Anaerobic/oxic (A/O) & [1501 \\
\hline China & Wastewater & 71 & 87 & Anaerobic/anoxic/anoxic/oxic MBR & {$[150]$} \\
\hline China & Wastewater & 1 & 100 & Anaerobic/aerobic/anoxic & [151] \\
\hline United States & Wastewater & -41 & $>99$ & CAS + Microfiltration & \\
\hline United States & Wastewater & 67 & 94 & Ozonation & [152] \\
\hline China & Wastewater & -53 & 100 & CAS & \\
\hline China & Wastewater & 53 & 100 & MBR & [153] \\
\hline China & Wastewater & -67 & 76 & BNR & \\
\hline Taiwan & Wastewater & 74 & $>99$ & $\mathrm{UF} / \mathrm{RO}+\mathrm{UV}$ & [53] \\
\hline
\end{tabular}

Note: $\mathrm{BNR}=$ biological nutrient removal, $\mathrm{CAS}=$ conventional activated sludge, $\mathrm{CW}=$ constructed wetland, $\mathrm{MBR}=$ membrane bioreactor, $\mathrm{RO}=$ reverse osmosis. $\mathrm{UF}=$ ultrafiltration, $\mathrm{UV}=$ ultraviolet irradiation.

\section{Conclusions}

The discovery of EPs in the environment indicated that several living organisms, including human beings, have long been exposed to potentially toxic micropollutants. PPCPs were among the most studied types of EPs due to their innate potential to cause significant biological effects. This study compiled the latest PPCP-related studies to create a synthesis of data regarding the occurrence, pathways, and effectiveness of different treatment technologies for PPCP removal. Over the past decade, studies focused on PPCPs exhibited an increasing trend. Approximately $90 \%$ of the published papers originated from Asia, Europe, and the North American regions. The widespread occurrence of PPCP compounds at different concentrations was identified in different matrices. Carbamazepine, 
caffeine, diclofenac were the most frequently reported compounds in water matrices. Since the characteristics of sludge and biosolids are primarily derived from wastewater, the frequent detection of carbamazepine and diclofenac was also observed in the samples. Different PPCP compounds were also detected in plant and animal tissues, indicating that some compounds are bioaccumulative. The environmental concentrations of PPCP compounds are greatly influenced by the efficiency of wastewater treatment technologies. Several studies indicated that existing conventional and advanced treatment processes were incapable of completely removing PPCP compounds from water and wastewater. Due to the complex degradation and retransformation patterns of some PPCP compounds, negative mass balances were observed in some treatment processes.

Along the process of compiling pertinent information, a number of knowledge gaps were also identified. There is a significant lack of research regarding the bioaccumulation potential of PPCPs in plants and animal tissues. As compared with water and solid matrices, studies on living organisms are relatively scarcer. The ecotoxicity and sublethal effects of PPCP compounds on different organisms can vary greatly and thus, a general conclusion regarding the burdens of PPCPs on non-target organisms remains uncertain. Finally, an absolute treatment technology for the effective removal of PPCP compounds in water and wastewater is still unavailable. While some studies suggest that advanced and supplementary treatments (i.e., MBR, ozonation, and UV irradiation) can enhance PPCP removal, there was also evidence that certain compounds are recalcitrant to degradation processes. The results of this study can be used to devise a more effective research paradigm and guidelines for PPCP management. Ultimately, further research initiatives are still recommended to address the knowledge gaps identified in this study.

Author Contributions: N.J.D.G.R.: conceptualization; investigation; formal analysis; software; writing-original draft preparation. F.K.F.G.: conceptualization; investigation; data curation; formal analysis; supervision. K.A.V.Y.: data curation; visualization; software. H.B.G.: software; data curation; formal Analysis. L.-H.K.: project administration; methodology; funding acquisition; supervision; validation; conceptualization; resources. All authors have read and agreed to the published version of the manuscript.

Funding: This work was supported by the research grant of Kongju National University (2020).

Institutional Review Board Statement: Not Applicable.

Informed Consent Statement: Not Applicable.

Data Availability Statement: The data presented in this study are available in the supplementary information.

Conflicts of Interest: The authors declare no conflict of interest.

\section{References}

1. Rosenfeld, P.E.; Feng, L.G. Emerging Contaminants. In Risks of Hazardous Wastes; Elsevier: Amsterdam, The Netherlands, 2011; pp. 215-222.

2. Murray, K.E.; Thomas, S.M.; Bodour, A.A. Prioritizing research for trace pollutants and emerging contaminants in the freshwater environment. Environ. Pollut. 2010, 158, 3462-3471. [CrossRef] [PubMed]

3. Rasheed, T.; Bilal, M.; Nabeel, F.; Adeel, M.; Iqbal, H.M. Environmentally-related contaminants of high concern: Potential sources and analytical modalities for detection, quantification, and treatment. Environ. Int. 2019, 122, 52-66. [CrossRef] [PubMed]

4. Daughton, C.G. Non-regulated water contaminants: Emerging research. Environ. Impact Assess. Rev. 2004, 24, 711-732. [CrossRef]

5. Hoenicke, R.; Oros, D.R.; Oram, J.J.; Taberski, K.M. Adapting an ambient monitoring program to the challenge of managing emerging pollutants in the San Francisco Estuary. Environ. Res. 2007, 105, 132-144. [CrossRef]

6. The American Chemical Society. CAS Registry-The Gold Standard for Chemical Substance Information. Available online: https://www.cas.org/support/documentation/chemical-substances (accessed on 31 March 2021).

7. Sangion, A.; Gramatica, P. Ecotoxicity interspecies QAAR models from Daphnia toxicity of pharmaceuticals and personal care products. SAR QSAR Environ. Res. 2016, 27, 781-798. [CrossRef]

8. Ebele, A.J.; Abdallah, M.A.-E.; Harrad, S. Pharmaceuticals and personal care products (PPCPs) in the freshwater aquatic environment. Emerg. Contam. 2017, 3, 1-16. [CrossRef] 
9. Garrison, A.W.; Pope, J.D.; Allen, F.R. GC/MS Analysis of Organic Compounds in Domestic Wastewaters. In Identification and Analysis of Organic Pollutants in Water; Ann Arbor Science: Ann Arbor, MI, USA, 1976.

10. Hignite, C.; Azarnoff, D.L. Drugs and drug metabolites as environmental contaminants: Chlorophenoxyisobutyrate and salicylic acid in sewage water effluent. Life Sci. 1977, 20, 337-341. [CrossRef]

11. Pfluger, P.; Dietrich, D.R. Effects on Pharmaceuticals in the Environment-An Overview and Principle Considerations. In Pharmaceuticals in the Environment; Springer: Berlin/Heidelberg, Germany, 2001; pp. 11-17.

12. Fu, W.; Fu, J.; Li, X.; Li, B.; Wang, X. Occurrence and fate of PPCPs in typical drinking water treatment plants in China. Environ. Geochem. Health 2018, 41, 5-15. [CrossRef]

13. Liu, S.; Wang, C.; Wang, P.; Chen, J.; Wang, X.; Yuan, Q. Anthropogenic disturbances on distribution and sources of pharmaceuticals and personal care products throughout the Jinsha River Basin, China. Environ. Res. 2020, 110449. [CrossRef]

14. Yuan, X.; Hu, J.; Li, S.; Yu, M. Occurrence, fate, and mass balance of selected pharmaceutical and personal care products (PPCPs) in an urbanized river. Environ. Pollut. 2020, 266, 115340. [CrossRef]

15. Junaid, M.; Wang, Y.; Hamid, N.; Deng, S.; Li, W.-G.; Pei, D.-S. Prioritizing selected PPCPs on the basis of environmental and toxicogenetic concerns: A toxicity estimation to confirmation approach. J. Hazard. Mater. 2019, 380, 120828. [CrossRef]

16. Kar, S.; Sanderson, H.; Roy, K.; Benfenati, E.; Leszczynski, J. Ecotoxicological assessment of pharmaceuticals and personal care products using predictive toxicology approaches. Green Chem. 2020, 22, 1458-1516. [CrossRef]

17. Liu, N.; Jin, X.; Feng, C.; Wang, Z.; Wu, F.; Johnson, A.C.; Xiao, H.; Hollert, H.; Giesy, J.P. Ecological risk assessment of fifty pharmaceuticals and personal care products (PPCPs) in Chinese surface waters: A proposed multiple-level system. Environ. Int. 2020, 136, 105454. [CrossRef]

18. Chen, Y.; Vymazal, J.; Březinová, T.; Koželuh, M.; Kule, L.; Huang, J.; Chen, Z. Occurrence, removal and environmental risk assessment of pharmaceuticals and personal care products in rural wastewater treatment wetlands. Sci. Total Environ. 2016, 566-567, 1660-1669. [CrossRef]

19. Paucar, N.E.; Kim, I.; Tanaka, H.; Sato, C. Ozone treatment process for the removal of pharmaceuticals and personal care products in wastewater. Ozone Sci. Eng. 2019, 41, 3-16. [CrossRef]

20. Papageorgiou, M.; Zioris, I.; Danis, T.; Bikiaris, D.; Lambropoulou, D. Comprehensive investigation of a wide range of pharmaceuticals and personal care products in urban and hospital wastewaters in Greece. Sci. Total Environ. 2019, $694,133565$. [CrossRef]

21. Júnior, C.A.M.; Luchiari, N.D.C.; Gomes, P.C.F.L. Occurrence of caffeine in wastewater and sewage and applied techniques for analysis: A review. Eclét. Quím. J. 2019, 44,11-26. [CrossRef]

22. Meyer, M.F.; Powers, S.M.; Hampton, S.E. An Evidence Synthesis of Pharmaceuticals and Personal Care Products (PPCPs) in the Environment: Imbalances among Compounds, Sewage Treatment Techniques, and Ecosystem Types. Environ. Sci. Technol. 2019, 53, 12961-12973. [CrossRef]

23. Liu, J.-L.; Wong, M.-H. Pharmaceuticals and personal care products (PPCPs): A review on environmental contamination in China. Environ. Int. 2013, 59, 208-224. [CrossRef]

24. Dai, G.; Huang, J.; Chen, W.; Wang, B.; Yu, G.; Deng, S. Major Pharmaceuticals and Personal Care Products (PPCPs) in Wastewater Treatment Plant and Receiving Water in Beijing, China, and Associated Ecological Risks. Bull. Environ. Contam. Toxicol. 2014, 92, 655-661. [CrossRef]

25. Jiang, X.; Qu, Y.; Liu, L.; He, Y.; Li, W.; Huang, J.; Yang, H.; Yu, G. PPCPs in a drinking water treatment plant in the Yangtze River Delta of China: Occurrence, removal and risk assessment. Front. Environ. Sci. Eng. 2019, 13, 27. [CrossRef]

26. Xie, H.; Hao, H.; Xu, N.; Liang, X.; Gao, D.; Xu, Y.; Gao, Y.; Tao, H.; Wong, M. Pharmaceuticals and personal care products in water, sediments, aquatic organisms, and fish feeds in the Pearl River Delta: Occurrence, distribution, potential sources, and health risk assessment. Sci. Total Environ. 2019, 659, 230-239. [CrossRef]

27. Wu, D.; Sui, Q.; Yu, X.; Zhao, W.; Li, Q.; Fatta-Kassinos, D.; Lyu, S. Identification of indicator PPCPs in landfill leachates and livestock wastewaters using multi-residue analysis of 70 PPCPs: Analytical method development and application in Yangtze River Delta, China. Sci. Total Environ. 2021, 753, 141653. [CrossRef]

28. Zheng, Y.; Lu, G.-H.; Shao, P.-W.; Piao, H.-T.; Gai, N.; Rao, Z.; Zhao, Q.-S.; Yang, Y.-L. Source Tracking and Risk Assessment of Pharmaceutical and Personal Care Products in Surface Waters of Qingdao, China, with Emphasis on Influence of Animal Farming in Rural Areas. Arch. Environ. Contam. Toxicol. 2020, 78, 579-588. [CrossRef]

29. Kolpin, D.W.; Furlong, E.T.; Meyer, M.T.; Thurman, E.M.; Zaugg, S.D.; Barber, L.B.; Buxton, H.T. Pharmaceuticals, Hormones, and Other Organic Wastewater Contaminants in U.S. Streams, 1999-2000: A National Reconnaissance. Environ. Sci. Technol. 2002, 36, 1202-1211. [CrossRef]

30. Zhang, S.; Gitungo, S.; Axe, L.; Dyksen, J.E.; Raczko, R.F. A pilot plant study using conventional and advanced water treatment processes: Evaluating removal efficiency of indicator compounds representative of pharmaceuticals and personal care products. Water Res. 2016, 105, 85-96. [CrossRef]

31. Brew, D.W.; Black, M.C.; Santos, M.; Rodgers, J.; Henderson, W.M. Metabolomic Investigations of the Temporal Effects of Exposure to Pharmaceuticals and Personal Care Products and Their Mixture in the Eastern Oyster (Crassostrea virginica). Environ. Toxicol. Chem. 2020, 39, 419-436. [CrossRef]

32. Meador, J.P.; Yeh, A.; Gallagher, E.P. Determining potential adverse effects in marine fish exposed to pharmaceuticals and personal care products with the fish plasma model and whole-body tissue concentrations. Environ. Pollut. 2017, 230, 1018-1029. [CrossRef] 
33. US FDA. Fact Sheet: FDA at a Glance. Available online: https://www.fda.gov/about-fda/fda-basics/fact-sheet-fda-glance (accessed on 23 February 2021).

34. Poynton, H.C.; Robinson, W.E. Contaminants of Emerging Concern, With an Emphasis on Nanomaterials and Pharmaceuticals. In Green Chemistry: An Inclusive Approach; Elsevier: Amsterdam, The Netherlands, 2018; pp. 291-315.

35. Jjemba, P.K. Excretion and ecotoxicity of pharmaceutical and personal care products in the environment. Ecotoxicol. Environ. Saf. 2006, 63, 113-130. [CrossRef]

36. Boxall, A.B.; Rudd, M.A.; Brooks, B.W.; Caldwell, D.J.; Choi, K.; Hickmann, S.; Innes, E.; Ostapyk, K.; Staveley, J.P.; Verslycke, T.; et al. Pharmaceuticals and Personal Care Products in the Environment: What Are the Big Questions? Environ. Health Perspect. 2012, 120, 1221-1229. [CrossRef]

37. Petrie, B.; Youdan, J.; Barden, R.; Kasprzyk-Hordern, B. New Framework to Diagnose the Direct Disposal of Prescribed Drugs in Wastewater-A Case Study of the Antidepressant Fluoxetine. Environ. Sci. Technol. 2016, 50, 3781-3789. [CrossRef] [PubMed]

38. Ternes, T.A.; Joss, A.; Siegrist, H. Peer Reviewed: Scrutinizing Pharmaceuticals and Personal Care Products in Wastewater Treatment. Environ. Sci. Technol. 2004, 38, 392A-399A. [CrossRef] [PubMed]

39. Doummar, J.; Geyer, T.; Baierl, M.; Nödler, K.; Licha, T.; Sauter, M. Carbamazepine breakthrough as indicator for specific vulnerability of karst springs: Application on the Jeita spring, Lebanon. Appl. Geochem. 2014, 47, 150-156. [CrossRef]

40. Hai, F.I.; Yang, S.; Asif, M.B.; Sencadas, V.; Shawkat, S.; Sanderson-Smith, M.; Gorman, J.; Xu, Z.-Q.; Yamamoto, K. Carbamazepine as a Possible Anthropogenic Marker in Water: Occurrences, Toxicological Effects, Regulations and Removal by Wastewater Treatment Technologies. Water 2018, 10, 107. [CrossRef]

41. Mitchell, D.C.; Knight, C.A.; Hockenberry, J.; Teplansky, R.; Hartman, T.J. Beverage caffeine intakes in the U.S. Food Chem. Toxicol. 2014, 63, 136-142. [CrossRef]

42. Li, S.; He, B.; Wang, J.; Liu, J.; Hu, X. Risks of caffeine residues in the environment: Necessity for a targeted ecopharmacovigilance program. Chemosphere 2020, 243, 125343. [CrossRef]

43. Lonappan, L.; Pulicharla, R.; Rouissi, T.; Brar, S.K.; Verma, M.; Surampalli, R.Y.; Valero, J.R. Diclofenac in municipal wastewater treatment plant: Quantification using laser diode thermal desorption-Atmospheric pressure chemical ionization-Tandem mass spectrometry approach in comparison with an established liquid chromatography-electrospray ionization-tandem mass spectrometry method. J. Chromatogr. A 2016, 1433, 106-113. [CrossRef]

44. Ustun Odabasi, S.; Buyukgungor, H. Removal of Diclofenac in Drinking Water with Fenton Process. Eur. Water 2017, 58, 41-46.

45. WHO; UNICEF. Progress on Sanitation and Drinking Water: 2015 Update and MDG Assessment; WHO: Geneva, Switzerland, 2015.

46. Andersson, K.; Rosemarin, A.; Lamizana, B.; Varnström, E.; McConville, J.; Seidu, R.; Dickin, S.; Trimmer, C. Sanitation, Wastewater Management and Sustainability: From Waste Disposal to Resource Recovery; United Nations Environment Program and Stockholm Environment Institute: Nairobi, Kenya; Stockholm, Sweden, 2020.

47. WWAP (United Nations World Water Assessment Programme). The United Nations World Water Development Report 2017. Wastewater: The Untapped Resource; UNESCO: Paris, France, 2017.

48. Archundia, D.; Duwig, C.; Spadini, L.; Morel, M.; Prado, B.; Perez, M.; Orsag, V.; Martins, J. Assessment of the Sulfamethoxazole mobility in natural soils and of the risk of contamination of water resources at the catchment scale. Environ. Int. 2019, 130, 104905. [CrossRef]

49. Mestre, A.S.; Carvalho, A.P. Photocatalytic Degradation of Pharmaceuticals Carbamazepine, Diclofenac, and Sulfamethoxazole by Semiconductor and Carbon Materials: A Review. Molecules 2019, 24, 3702. [CrossRef]

50. Contreras, C.R.; López, D.; Leiva, A.M.; Domínguez, C.; Bayona, J.M.; Vidal, G. Removal of Organic Micropollutants in Wastewater Treated by Activated Sludge and Constructed Wetlands: A Comparative Study. Water 2019, 11, 2515. [CrossRef]

51. Masoner, J.R.; Kolpin, D.W.; Cozzarelli, I.M.; Barber, L.B.; Burden, D.S.; Foreman, W.T.; Forshay, K.J.; Furlong, E.T.; Groves, J.F.; Hladik, M.L.; et al. Urban Stormwater: An Overlooked Pathway of Extensive Mixed Contaminants to Surface and Groundwaters in the United States. Environ. Sci. Technol. 2019, 53, 10070-10081. [CrossRef]

52. Carrard, N.; Foster, T.; Willetts, J. Groundwater as a Source of Drinking Water in Southeast Asia and the Pacific: A Multi-Country Review of Current Reliance and Resource Concerns. Water 2019, 11, 1605. [CrossRef]

53. Lin, A.Y.-C.; Tsai, Y.-T.; Yu, T.-H.; Wang, X.-H.; Lin, C.-F. Occurrence and fate of pharmaceuticals and personal care products in Taiwan's aquatic environment. Desalin. Water Treat. 2011, 32, 57-64. [CrossRef]

54. Sui, Q.; Cao, X.; Lu, S.; Zhao, W.; Qiu, Z.; Yu, G. Occurrence, sources and fate of pharmaceuticals and personal care products in the groundwater: A review. Emerg. Contam. 2015, 1, 14-24. [CrossRef]

55. Tran, N.H.; Li, J.; Hu, J.; Ong, S.L. Occurrence and suitability of pharmaceuticals and personal care products as molecular markers for raw wastewater contamination in surface water and groundwater. Environ. Sci. Pollut. Res. 2013, 21, 4727-4740. [CrossRef]

56. Kibuye, F.A.; Gall, H.E.; Elkin, K.R.; Ayers, B.; Veith, T.L.; Miller, M.; Jacob, S.; Hayden, K.R.; Watson, J.E.; Elliott, H.A. Fate of pharmaceuticals in a spray-irrigation system: From wastewater to groundwater. Sci. Total Environ. 2019, 654, 197-208. [CrossRef]

57. Lockwood, S.; Saïdi, N.; Morgan, V.A. Options for a Strategic Approach to Pharmaceuticals in the Environment: Task 1 Report-Revised Version; European Union: Luxembourg City, Luxembourg, 2016.

58. Padhye, L.P.; Yao, H.; Kung'U, F.T.; Huang, C.-H. Year-long evaluation on the occurrence and fate of pharmaceuticals, personal care products, and endocrine disrupting chemicals in an urban drinking water treatment plant. Water Res. 2014, 51, 266-276. [CrossRef] 
59. Datel, J.V.; Hrabankova, A. Pharmaceuticals Load in the Svihov Water Reservoir (Czech Republic) and Impacts on Quality of Treated Drinking Water. Water 2020, 12, 1387. [CrossRef]

60. Ungureanu, N.; Vlăduț, V.; Voicu, G. Water Scarcity and Wastewater Reuse in Crop Irrigation. Sustainability 2020, $12,9055$. [CrossRef]

61. Gruère, G.; Shigemitsu, M.; Crawford, S. Agriculture and Water Policy Changes: Stocktaking and Alignment with OECD and G20 Recommendations; OECD Publishing: Paris, France, 2020. [CrossRef]

62. Tortajada, C.; Nambiar, S. Communications on Technological Innovations: Potable Water Reuse. Water 2019, 11, 251. [CrossRef]

63. Tortajada, C. Contributions of recycled wastewater to clean water and sanitation Sustainable Development Goals. NPJ Clean Water 2020, 3, 1-6. [CrossRef]

64. Kinney, C.A.; Furlong, E.T.; Werner, S.L.; Cahill, J.D. Presence and distribution of wastewater-derived pharmaceuticals in soil irrigated with reclaimed water. Environ. Toxicol. Chem. 2006, 25, 317-326. [CrossRef]

65. Chen, F.; Ying, G.-G.; Kong, L.-X.; Wang, L.; Zhao, J.-L.; Zhou, L.-J.; Zhang, L.-J. Distribution and accumulation of endocrinedisrupting chemicals and pharmaceuticals in wastewater irrigated soils in Hebei, China. Environ. Pollut. 2011, 159, 1490-1498. [CrossRef]

66. Lamastra, L.; Suciu, N.A.; Trevisan, M. Sewage sludge for sustainable agriculture: Contaminants' contents and potential use as fertilizer. Chem. Biol. Technol. Agric. 2018, 5, 10. [CrossRef]

67. Dong, R.; Yu, G.; Guan, Y.; Wang, B.; Huang, J.; Deng, S.; Wang, Y. Occurrence and discharge of pharmaceuticals and personal care products in dewatered sludge from WWTPs in Beijing and Shenzhen. Emerg. Contam. 2016, 2, 1-6. [CrossRef]

68. Morissette, M.-F.; Duy, S.V.; Arp, H.P.H.; Sauvé, S. Sorption and desorption of diverse contaminants of varying polarity in wastewater sludge with and without alum. Environ. Sci. Process. Impacts 2015, 17, 674-682. [CrossRef] [PubMed]

69. Suárez, S.; Carballa, M.; Omil, F.; Lema, J.M. How are pharmaceutical and personal care products (PPCPs) removed from urban wastewaters? Rev. Environ. Sci. Bio/Technol. 2008, 7, 125-138. [CrossRef]

70. Brose, D.A.; Kumar, K.; Liao, A.; Hundal, L.S.; Tian, G.; Cox, A.; Zhang, H.; Podczerwinski, E.W. A reduction in triclosan and triclocarban in water resource recovery facilities' influent, effluent, and biosolids following the U.S. Food and Drug Administration's 2013 proposed rulemaking on antibacterial products. Water Environ. Res. 2019, 91, 715-721. [CrossRef] [PubMed]

71. Healy, M.; Fenton, O.; Cormican, M.; Peyton, D.; Ordsmith, N.; Kimber, K.; Morrison, L. Antimicrobial compounds (triclosan and triclocarban) in sewage sludges, and their presence in runoff following land application. Ecotoxicol. Environ. Saf. 2017, 142, 448-453. [CrossRef] [PubMed]

72. Keerthanan, S.; Jayasinghe, C.; Biswas, J.K.; Vithanage, M. Pharmaceutical and Personal Care Products (PPCPs) in the environment: Plant uptake, translocation, bioaccumulation, and human health risks. Crit. Rev. Environ. Sci. Technol. 2020, 1-38. [CrossRef]

73. Al-Farsi, R.S.; Ahmed, M.; Al-Busaidi, A.; Choudri, B. Translocation of pharmaceuticals and personal care products (PPCPs) into plant tissues: A review. Emerg. Contam. 2017, 3, 132-137. [CrossRef]

74. Miller, E.L.; Nason, S.L.; Karthikeyan, K.G.; Pedersen, J.A. Root Uptake of Pharmaceuticals and Personal Care Product Ingredients. Environ. Sci. Technol. 2016, 50, 525-541. [CrossRef]

75. Arnnok, P.; Singh, R.R.; Burakham, R.; Pérez-Fuentetaja, A.; Aga, D.S. Selective Uptake and Bioaccumulation of Antidepressants in Fish from Effluent-Impacted Niagara River. Environ. Sci. Technol. 2017, 51, 10652-10662. [CrossRef]

76. Muir, D.; Simmons, D.; Wang, X.; Peart, T.; Villella, M.; Miller, J.; Sherry, J. Bioaccumulation of pharmaceuticals and personal care product chemicals in fish exposed to wastewater effluent in an urban wetland. Sci. Rep. 2017, 7, 1-11. [CrossRef]

77. Tanoue, R.; Nozaki, K.; Nomiyama, K.; Kunisue, T.; Tanabe, S. Rapid analysis of 65 pharmaceuticals and 7 personal care products in plasma and whole-body tissue samples of fish using acidic extraction, zirconia-coated silica cleanup, and liquid chromatography-tandem mass spectrometry. J. Chromatogr. A 2020, 1631, 461586. [CrossRef]

78. Jjemba, P.K. Pharma-Ecology: The Occurrence and Fate of Pharmaceuticals and Personal Care Products in the Environment, 2nd ed.; John Wiley \& Sons: Hoboken, NJ, USA, 2018. [CrossRef]

79. Jabusch, T.W.; Swackhamer, D.L. Subcellular accumulation of polychlorinated biphenyls in the green alga chlamydomonas reinhardtii. Environ. Toxicol. Chem. 2004, 23, 2823-2830. [CrossRef]

80. Coogan, M.A.; Edziyie, R.E.; La Point, T.W.; Venables, B.J. Algal bioaccumulation of triclocarban, triclosan, and methyl-triclosan in a North Texas wastewater treatment plant receiving stream. Chemosphere 2007, 67, 1911-1918. [CrossRef]

81. Lagesson, A.; Fahlman, J.; Brodin, T.; Fick, J.; Jonsson, M.; Byström, P.; Klaminder, J. Bioaccumulation of five pharmaceuticals at multiple trophic levels in an aquatic food web-Insights from a field experiment. Sci. Total Environ. 2016, 568, 208-215. [CrossRef]

82. Peng, X.; Ou, W.; Wang, C.; Wang, Z.; Huang, Q.; Jin, J.; Tan, J. Occurrence and ecological potential of pharmaceuticals and personal care products in groundwater and reservoirs in the vicinity of municipal landfills in China. Sci. Total Environ. 2014, 490, 889-898. [CrossRef]

83. Deng, W.-J.; Li, N.; Wu, R.; Richard, W.K.; Wang, Z.; Ho, W. Phosphorus flame retardants and Bisphenol A in indoor dust and PM2.5 in kindergartens and primary schools in Hong Kong. Environ. Pollut. 2018, 235, 365-371. [CrossRef]

84. Konduracka, E.; Krzemieniecki, K.; Gajos, G. Relationship between everyday use cosmetics and female breast cancer. Pol. Arch. Intern. Med. 2014, 124, 264-269. [CrossRef]

85. Rotimi, O.A.; Olawole, T.D.; De Campos, O.C.; Adelani, I.B.; Rotimi, S.O. Bisphenol A in Africa: A review of environmental and biological levels. Sci. Total Environ. 2021, 764, 142854. [CrossRef] 
86. Huang, Y.; Wong, C.; Zheng, J.; Bouwman, H.; Barra, R.; Wahlström, B.; Neretin, L.; Wong, M. Bisphenol A (BPA) in China: A review of sources, environmental levels, and potential human health impacts. Environ. Int. 2012, 42, 91-99. [CrossRef]

87. Archana, G.; Dhodapkar, R.; Kumar, A. Ecotoxicological risk assessment and seasonal variation of some pharmaceuticals and personal care products in the sewage treatment plant and surface water bodies (lakes). Environ. Monit. Assess. 2017, $189,446$. [CrossRef]

88. Tamura, I.; Yasuda, Y.; Kagota, K.-I.; Yoneda, S.; Nakada, N.; Kumar, V.; Kameda, Y.; Kimura, K.; Tatarazako, N.; Yamamoto, H. Contribution of pharmaceuticals and personal care products (PPCPs) to whole toxicity of water samples collected in effluentdominated urban streams. Ecotoxicol. Environ. Saf. 2017, 144, 338-350. [CrossRef]

89. Picó, Y.; Alvarez-Ruiz, R.; Alfarhan, A.H.; El-Sheikh, M.A.; Alshahrani, H.O.; Barceló, D. Pharmaceuticals, pesticides, personal care products and microplastics contamination assessment of Al-Hassa irrigation network (Saudi Arabia) and its shallow lakes. Sci. Total Environ. 2020, 701, 135021. [CrossRef]

90. Kumar, R. Fate of Pharmaceuticals and Personal Care Products (PPCPs) and Drugs of Abuse in a Wastewater Treatment Plant of New Zealand and the Photocatalytic Removal of Selected PPCPs with Poly (3,4-Ethylenedioxythiophene). Ph.D. Thesis, The University of Auckland, Auckland, New Zealand, 2020.

91. Mandaric, L.; Diamantini, E.; Stella, E.; Cano-Paoli, K.; Valle-Sistac, J.; Molins-Delgado, D.; Bellin, A.; Chiogna, G.; Majone, B.; Diaz-Cruz, M.S.; et al. Contamination sources and distribution patterns of pharmaceuticals and personal care products in Alpine rivers strongly affected by tourism. Sci. Total Environ. 2017, 590-591, 484-494. [CrossRef]

92. Ebele, A.J.; Oluseyi, T.; Drage, D.S.; Harrad, S.; Abdallah, M.A.-E. Occurrence, seasonal variation and human exposure to pharmaceuticals and personal care products in surface water, groundwater and drinking water in Lagos State, Nigeria. Emerg. Contam. 2020, 6, 124-132. [CrossRef]

93. Yu, Y.; Wu, L.; Chang, A.C. Seasonal variation of endocrine disrupting compounds, pharmaceuticals and personal care products in wastewater treatment plants. Sci. Total Environ. 2013, 442, 310-316. [CrossRef]

94. Raval, A.D.; Vyas, A. National Trends in Diabetes Medication Use in the United States: 2008 to 2015. J. Pharm. Pract. 2020, 33, 433-442. [CrossRef]

95. Chaves, M.D.J.S.; Barbosa, S.C.; Malinowski, M.D.M.; Volpato, D.; Castro Ítalo, B.; Franco, T.C.R.D.S.; Primel, E.G. Pharmaceuticals and personal care products in a Brazilian wetland of international importance: Occurrence and environmental risk assessment. Sci. Total Environ. 2020, 734, 139374. [CrossRef] [PubMed]

96. Aristizabal-Ciro, C.; Botero-Coy, A.M.; López, F.J.; Peñuela, G.A. Monitoring pharmaceuticals and personal care products in reservoir water used for drinking water supply. Environ. Sci. Pollut. Res. 2017, 24, 7335-7347. [CrossRef] [PubMed]

97. Huber, S.; Remberger, M.; Kaj, L.; Schlabach, M.; Jörundsdóttir, H.Ó.; Vester, J.; Arnórsson, M.; Mortensen, I.; Schwartson, R.; Dam, M. A first screening and risk assessment of pharmaceuticals and additives in personal care products in waste water, sludge, recipient water and sediment from Faroe Islands, Iceland and Greenland. Sci. Total Environ. 2016, 562, 13-25. [CrossRef] [PubMed]

98. Ashfaq, M.; Li, Y.; Rehman, M.S.U.; Zubair, M.; Mustafa, G.; Nazar, M.F.; Yu, C.-P.; Sun, Q. Occurrence, spatial variation and risk assessment of pharmaceuticals and personal care products in urban wastewater, canal surface water, and their sediments: A case study of Lahore, Pakistan. Sci. Total Environ. 2019, 688, 653-663. [CrossRef] [PubMed]

99. Wang, Y.; Li, Y.; Hu, A.; Rashid, A.; Ashfaq, M.; Wang, Y.; Wang, H.; Luo, H.; Yu, C.-P.; Sun, Q. Monitoring, mass balance and fate of pharmaceuticals and personal care products in seven wastewater treatment plants in Xiamen City, China. J. Hazard. Mater. 2018, 354, 81-90. [CrossRef] [PubMed]

100. Narumiya, M.; Nakada, N.; Yamashita, N.; Tanaka, H. Phase distribution and removal of pharmaceuticals and personal care products during anaerobic sludge digestion. J. Hazard. Mater. 2013, 260, 305-312. [CrossRef] [PubMed]

101. Bourdat-Deschamps, M.; Ferhi, S.; Bernet, N.; Feder, F.; Crouzet, O.; Patureau, D.; Montenach, D.; Moussard, G.D.; Mercier, V.; Benoit, P.; et al. Fate and impacts of pharmaceuticals and personal care products after repeated applications of organic waste products in long-term field experiments. Sci. Total Environ. 2017, 607-608, 271-280. [CrossRef]

102. Brown, S.; Kennedy, L.; Cullington, M.; Mihle, A.; Lono-Batura, M. Relating Pharmaceuticals and Personal Care Products in Biosolids to Home Exposure. Urban Agric. Reg. Food Syst. 2019, 4, 1-14. [CrossRef]

103. Rhodes, G.; Chuang, Y.-H.; Hammerschmidt, R.; Zhang, W.; Boyd, S.A.; Li, H. Uptake of cephalexin by lettuce, celery, and radish from water. Chemosphere 2021, 263, 127916. [CrossRef]

104. Mlynek, F.; Himmelsbach, M.; Buchberger, W.; Klampfl, C.W. Time study on the uptake of four different beta-blockers in garden cress (Lepidium sativum) as a model plant. Environ. Sci. Pollut. Res. 2020. [CrossRef]

105. Beltrán, E.M.; Pablos, M.V.; Torija, C.F.; Porcel, M. Ángel; González-Doncel, M. Uptake of atenolol, carbamazepine and triclosan by crops irrigated with reclaimed water in a Mediterranean scenario. Ecotoxicol. Environ. Saf. 2020, 191, 110171. [CrossRef]

106. Liu, X.; Liang, C.; Liu, X.; Zhao, F.; Han, C. Occurrence and human health risk assessment of pharmaceuticals and personal care products in real agricultural systems with long-term reclaimed wastewater irrigation in Beijing, China. Ecotoxicol. Environ. Saf. 2020, 190, 110022. [CrossRef]

107. Wang, Y.; Yin, T.; Kelly, B.C.; Gin, K.Y.-H. Bioaccumulation behaviour of pharmaceuticals and personal care products in a constructed wetland. Chemosphere 2019, 222, 275-285. [CrossRef]

108. Subedi, B.; Du, B.; Chambliss, C.K.; Koschorreck, J.; Rüdel, H.; Quack, M.; Brooks, B.W.; Usenko, S. Occurrence of Pharmaceuticals and Personal Care Products in German Fish Tissue: A National Study. Environ. Sci. Technol. 2012, 46, 9047-9054. [CrossRef] 
109. Fussell, R.J.; Lopez, M.G.; Mortimer, D.N.; Wright, S.; Sehnalova, M.; Sinclair, C.J.; Fernandes, A.; Sharman, M. Investigation into the Occurrence in Food of Veterinary Medicines, Pharmaceuticals, and Chemicals Used in Personal Care Products. J. Agric. Food Chem. 2014, 62, 3651-3659. [CrossRef]

110. Tanoue, R.; Nomiyama, K.; Nakamura, H.; Kim, J.-W.; Isobe, T.; Shinohara, R.; Kunisue, T.; Tanabe, S. Uptake and Tissue Distribution of Pharmaceuticals and Personal Care Products in Wild Fish from Treated-Wastewater-Impacted Streams. Environ. Sci. Technol. 2015, 49, 11649-11658. [CrossRef]

111. De Solla, S.; Gilroy, È.A.M.; Klinck, J.; King, L.; McInnis, R.; Struger, J.; Backus, S.; Gillis, P. Bioaccumulation of pharmaceuticals and personal care products in the unionid mussel Lasmigona costata in a river receiving wastewater effluent. Chemosphere 2016, 146, 486-496. [CrossRef]

112. Xin, X.; Huang, G.; Liu, X.; An, C.; Yao, Y.; Weger, H.; Zhang, P.; Chen, X. Molecular toxicity of triclosan and carbamazepine to green algae Chlorococcum sp.: A single cell view using synchrotron-based Fourier transform infrared spectromicroscopy. Environ. Pollut. 2017, 226, 12-20. [CrossRef]

113. Rubasinghege, G.; Gurung, R.; Rijal, H.; Maldonado-Torres, S.; Chan, A.; Acharya, S.; Rogelj, S.; Piyasena, M. Abiotic degradation and environmental toxicity of ibuprofen: Roles of mineral particles and solar radiation. Water Res. 2018, 131, 22-32. [CrossRef]

114. Qiu, Z.; Sun, J.; Han, D.; Wei, F.; Mei, Q.; Wei, B.; Wang, X.; An, Z.; Bo, X.; Li, M.; et al. Ozonation of diclofenac in the aqueous solution: Mechanism, kinetics and ecotoxicity assessment. Environ. Res. 2020, 188, 109713. [CrossRef] [PubMed]

115. Parolini, M.; Binelli, A.; Provini, A. Chronic effects induced by ibuprofen on the freshwater bivalve Dreissena polymorpha. Ecotoxicol. Environ. Saf. 2011, 74, 1586-1594. [CrossRef] [PubMed]

116. Kohlert, J.G.; Mangan, B.P.; Kodra, C.; Drako, L.; Long, E.; Simpson, H. Decreased Aggressive and Locomotor Behaviors in Betta Splendens after Exposure to Fluoxetine. Psychol. Rep. 2012, 110, 51-62. [CrossRef] [PubMed]

117. Huang, S.S.; Benskin, J.P.; Veldhoen, N.; Chandramouli, B.; Butler, H.; Helbing, C.C.; Cosgrove, J.R. A multi-omic approach to elucidate low-dose effects of xenobiotics in zebrafish (Danio rerio) larvae. Aquat. Toxicol. 2017, 182, 102-112. [CrossRef]

118. Archer, E.; Wolfaardt, G.M.; Van Wyk, J.H. Review: Pharmaceutical and personal care products (PPCPs) as endocrine disrupting contaminants (EDCs) in South African surface waters. Water SA 2017, 43, 684. [CrossRef]

119. Richmond, E.K.; Grace, M.R.; Kelly, J.J.; Reisinger, A.J.; Rosi, E.J.; Walters, D.M. Pharmaceuticals and personal care products (PPCPs) are ecological disrupting compounds (EcoDC). Elementa 2017, 5. [CrossRef]

120. Gonzalez-Rey, M.; Bebianno, M.J. Does non-steroidal anti-inflammatory (NSAID) ibuprofen induce antioxidant stress and endocrine disruption in mussel Mytilus galloprovincialis? Environ. Toxicol. Pharmacol. 2012, 33, 361-371. [CrossRef]

121. Escapa, C.; Coimbra, R.N.; Neuparth, T.; Torres, T.; Santos, M.M.; Otero, M. Acetaminophen Removal from Water by Microalgae and Effluent Toxicity Assessment by the Zebrafish Embryo Bioassay. Water 2019, 11, 1929. [CrossRef]

122. Capolupo, M.; Valbonesi, P.; Kiwan, A.; Buratti, S.; Franzellitti, S.; Fabbri, E. Use of an integrated biomarker-based strategy to evaluate physiological stress responses induced by environmental concentrations of caffeine in the Mediterranean mussel Mytilus galloprovincialis. Sci. Total Environ. 2016, 563-564, 538-548. [CrossRef]

123. Prasad, M.N.V.; Vithanage, M.; Kapley, A. Pharmaceuticals and Personal Care Products: Waste Management and Treatment Technology Emerging Contaminants and Micro Pollutants; Butterworth-Heinemann: Oxford, UK, 2019. [CrossRef]

124. Tang, Y.; Li, X.-M.; Xu, Z.-C.; Guo, Q.-W.; Hong, C.-Y.; Bing, Y.-X. Removal of naproxen and bezafibrate by activated sludge under aerobic conditions: Kinetics and effect of substrates. Biotechnol. Appl. Biochem. 2014, 61. [CrossRef]

125. Hatoum, R.; Potier, O.; Roques-Carmes, T.; Lemaitre, C.; Hamieh, T.; Toufaily, J.; Horn, H.; Borowska, E.; Carmes, R. Horn Elimination of Micropollutants in Activated Sludge Reactors with a Special Focus on the Effect of Biomass Concentration. Water 2019, 11, 2217. [CrossRef]

126. Tran, N.H.; Gin, K.Y.-H. Occurrence and removal of pharmaceuticals, hormones, personal care products, and endocrine disrupters in a full-scale water reclamation plant. Sci. Total Environ. 2017, 599-600, 1503-1516. [CrossRef]

127. Kumar, R.; Sarmah, A.K.; Padhye, L.P. Fate of pharmaceuticals and personal care products in a wastewater treatment plant with parallel secondary wastewater treatment train. J. Environ. Manag. 2019, 233, 649-659. [CrossRef]

128. Pai, C.-W.; Leong, D.; Chen, C.-Y.; Wang, G.-S. Occurrences of pharmaceuticals and personal care products in the drinking water of Taiwan and their removal in conventional water treatment processes. Chemosphere 2020, 256, 127002. [CrossRef]

129. Fung, C.S.; Khan, M.; Kumar, A.; Lo, I.M. Visible-light-driven photocatalytic removal of PPCPs using magnetically separable bismuth oxybromo-iodide solid solutions: Mechanisms, pathways, and reusability in real sewage. Sep. Purif. Technol. 2019, 216, 102-114. [CrossRef]

130. Xiao, J.; Xie, Y.; Cao, H. Organic pollutants removal in wastewater by heterogeneous photocatalytic ozonation. Chemosphere 2015, 121, 1-17. [CrossRef]

131. Mecha, A.C.; Chollom, M.N. Photocatalytic ozonation of wastewater: A review. Environ. Chem. Lett. 2020, $18,1491-1507$. [CrossRef]

132. Aguinaco, A.; Beltrán, F.J.; García-Araya, J.F.; Oropesa, A.L. Photocatalytic ozonation to remove the pharmaceutical diclofenac from water: Influence of variables. Chem. Eng. J. 2012, 189-190, 275-282. [CrossRef]

133. Márquez, G.; Rodríguez, E.M.; Beltrán, F.J.; Álvarez, P.M. Solar photocatalytic ozonation of a mixture of pharmaceutical compounds in water. Chemosphere 2014, 113, 71-78. [CrossRef] 
134. Hojamberdiev, M.; Czech, B.; Göktaş, A.C.; Yubuta, K.; Kadirova, Z.C. SnO2@ZnS photocatalyst with enhanced photocatalytic activity for the degradation of selected pharmaceuticals and personal care products in model wastewater. J. Alloy. Compd. 2020, 827, 154339. [CrossRef]

135. Grassi, M.; Rizzo, L.; Farina, A. Endocrine disruptors compounds, pharmaceuticals and personal care products in urban wastewater: Implications for agricultural reuse and their removal by adsorption process. Environ. Sci. Pollut. Res. 2013, 20, 3616-3628. [CrossRef] [PubMed]

136. Seo, P.W.; Bhadra, B.N.; Ahmed, I.; Khan, N.A.; Jhung, S.H. Adsorptive Removal of Pharmaceuticals and Personal Care Products from Water with Functionalized Metal-organic Frameworks: Remarkable Adsorbents with Hydrogen-bonding Abilities. Sci. Rep. 2016, 6, 34462. [CrossRef] [PubMed]

137. Yi, C.; Qin, W.; Wen, X. Renovated filter filled with poly-3-hydroxybutyrateco-hydroxyvalerate and granular activated carbon for simultaneous removal of nitrate and PPCPs from the secondary effluent. Sci. Total Environ. 2020, 749, 141494. [CrossRef]

138. Rodriguez, E.; Campinas, M.; Acero, J.L.; Rosa, M.J. Investigating PPCP Removal from Wastewater by Powdered Activated Carbon/Ultrafiltration. Water Air Soil Pollut. 2016, 227, 1-14. [CrossRef]

139. Gizińska-Górna, M.; Czekała, W.; Jóźwiakowski, K.; Lewicki, A.; Dach, J.; Marzec, M.; Pytka, A.; Janczak, D.; Kowalczyk-Juśko, A.; Listosz, A. The possibility of using plants from hybrid constructed wetland wastewater treatment plant for energy purposes. Ecol. Eng. 2016, 95, 534-541. [CrossRef]

140. Almuktar, S.A.A.A.N.; Abed, S.N.; Scholz, M. Wetlands for wastewater treatment and subsequent recycling of treated effluent: A review. Environ. Sci. Pollut. Res. 2018, 25, 23595-23623. [CrossRef] [PubMed]

141. Zhang, Y.; Geißen, S.-U.; Gal, C. Carbamazepine and diclofenac: Removal in wastewater treatment plants and occurrence in water bodies. Chemosphere 2008, 73, 1151-1161. [CrossRef] [PubMed]

142. Xu, J.; Li, L.; Guo, C.; Zhang, Y.; Meng, W. Photocatalytic degradation of carbamazepine by tailored BiPO4: Efficiency, intermediates and pathway. Appl. Catal. B Environ. 2013, 130-131, 285-292. [CrossRef]

143. Hoque, M.E.; Cloutier, F.; Arcieri, C.; McInnes, M.; Sultana, T.; Murray, C.; Vanrolleghem, P.A.; Metcalfe, C.D. Removal of selected pharmaceuticals, personal care products and artificial sweetener in an aerated sewage lagoon. Sci. Total Environ. 2014, 487, 801-812. [CrossRef]

144. Blair, B.; Nikolaus, A.; Hedman, C.; Klaper, R.; Grundl, T. Evaluating the degradation, sorption, and negative mass balances of pharmaceuticals and personal care products during wastewater treatment. Chemosphere 2015, 134, 395-401. [CrossRef]

145. Park, J.; Yamashita, N.; Park, C.; Shimono, T.; Takeuchi, D.M.; Tanaka, H. Removal characteristics of pharmaceuticals and personal care products: Comparison between membrane bioreactor and various biological treatment processes. Chemosphere 2017, 179, 347-358. [CrossRef] [PubMed]

146. Sui, Q.; Zhao, W.; Cao, X.; Lu, S.; Qiu, Z.; Gu, X.; Yu, G. Pharmaceuticals and personal care products in the leachates from a typical landfill reservoir of municipal solid waste in Shanghai, China: Occurrence and removal by a full-scale membrane bioreactor. J. Hazard. Mater. 2017, 323, 99-108. [CrossRef] [PubMed]

147. Nakada, N.; Hanamoto, S.; Juergens, M.D.; Johnson, A.C.; Bowes, M.J.; Tanaka, H. Assessing the population equivalent and performance of wastewater treatment through the ratios of pharmaceuticals and personal care products present in a river basin: Application to the River Thames basin, UK. Sci. Total Environ. 2017, 575, 1100-1108. [CrossRef]

148. Tan, E.S.S.; Bin Ho, Y.; Zakaria, M.P.; Latif, P.A.; Saari, N. Simultaneous extraction and determination of pharmaceuticals and personal care products (PPCPs) in river water and sewage by solid-phase extraction and liquid chromatography-tandem mass spectrometry. Int. J. Environ. Anal. Chem. 2015, 1-17. [CrossRef]

149. Dai, G.; Wang, B.; Fu, C.; Dong, R.; Huang, J.; Deng, S.; Wang, Y.; Yu, G. Pharmaceuticals and personal care products (PPCPs) in urban and suburban rivers of Beijing, China: Occurrence, source apportionment and potential ecological risk. Environ. Sci. Process. Impacts 2016, 18, 445-455. [CrossRef]

150. He, Y.-J.; Chen, W.; Zheng, X.-Y.; Wang, X.-N.; Huang, X. Fate and removal of typical pharmaceuticals and personal care products by three different treatment processes. Sci. Total Environ. 2013, 447, 248-254. [CrossRef]

151. Chen, H.; Li, X.; Zhu, S. Occurrence and distribution of selected pharmaceuticals and personal care products in aquatic environments: A comparative study of regions in China with different urbanization levels. Environ. Sci. Pollut. Res. 2012, 19, 2381-2389. [CrossRef]

152. Yang, X.; Flowers, R.C.; Weinberg, H.S.; Singer, P.C. Occurrence and removal of pharmaceuticals and personal care products (PPCPs) in an advanced wastewater reclamation plant. Water Res. 2011, 45, 5218-5228. [CrossRef] [PubMed]

153. Sui, Q.; Huang, J.; Deng, S.; Chen, W.; Yu, G. Seasonal Variation in the Occurrence and Removal of Pharmaceuticals and Personal Care Products in Different Biological Wastewater Treatment Processes. Environ. Sci. Technol. 2011, 45, 3341-3348. [CrossRef] 